Article

\title{
Switched Energy Management Strategy for Fuel Cell Hybrid Vehicle Based on Switch Network
}

\author{
Xu Chen, Guangdi Hu *, Feng Guo, Mengqi Ye and Jingyuan Huang \\ School of Mechanical Engineering, Southwest Jiaotong University, Chengdu 610031, China; \\ chenxu_aca@my.swjtu.edu.cn (X.C.); fguo@my.swjtu.edu.cn (F.G.); ymqsidda@163.com (M.Y.); \\ Huangjingyuan@my.swjtu.edu.cn (J.H.) \\ * Correspondence: ghu@swjtu.edu.cn; Tel.: +86-186-2826-4826
}

Received: 18 December 2019; Accepted: 30 December 2019; Published: 3 January 2020

\begin{abstract}
Environmentally friendly and pollution-free fuel cell/lithium battery hybrid vehicles have received the attention of the community in recent years. It is imperative for fuel cell/lithium battery hybrid vehicles to use the energy management strategy (EMS) to distribute the output power of each power source to improve fuel economy and system life. In practical application, inconsistency of battery pack will lead to security hazard and capacity degradation. However, few EMS take the inconsistency of battery pack into account. Also, the current battery equalization strategy rarely discusses how to perform the equilibrium process while meeting the power demand of vehicle. To solve these issues, a novel equalization energy management strategy (EEMS) based on the switch network is proposed at first. Then, a switched energy management strategy (SEMS) that switches between the EEMS and the equivalent consumption minimization strategy (ECMS) is proposed and implemented in the fuel cell/lithium battery hybrid system to validate its effectiveness. The results show that the proposed SEMS can ameliorate the inconsistency of series lithium battery pack while meeting the power demand of vehicle's normal operation. It can improve the safety and durability of the system and reduce the equalization time. Besides, it has good expansibility and no energy waste.
\end{abstract}

Keywords: hybrid system; EMS; equalization; switch network; ECMS

\section{Introduction}

In recent years, the world's environmental pollution and energy shortages have become increasingly serious. Not only in China, but also worldwide, the carbon emissions of metallurgical industry, shipping, aerospace and other industries have attracted the attention of the community [1-5]. Many regions and industries have released relevant regulations to limit carbon emissions. So, the development of traditional fuel vehicles has been limited [6-8]. To reduce exhaust emissions and energy consumption, it has become an irresistible trend for the automotive industry to replace fossil fuels by using electricity and other clean energy [9-11]. Batteries have high energy density, fast dynamic response, and no pollution. They are widely used in electric vehicles. However, batteries also have some shortcomings, such as low power density, long charging time, and short life [12,13]. Fuel cells with high efficiency and no pollution are ideal fossil energy alternatives. However, fuel cell stacks require flow supply, diffusion and catalysis, which lead to slow dynamic response. Hybrid vehicles can combine the advantages of fuel cells and lithium batteries, and have high development prospects $[14,15]$.

EMS is the basis for the good performance of hybrid vehicles. The key issue is the energy distribution in hybrid systems under various operating conditions [16,17]. EMS mainly includes rule-based control strategies and optimization-based control strategies [18-20]. 
The rule-based control strategy uses deterministic rules or fuzzy logic rules to distribute power among multiple power sources. Li [21] proposed a state machine EMS based on droop control for hybrid tramway, which can meet the rapidly changing power demand and improve the system efficiency. Xiao [22] has proposed an EMS based on operation mode. Based on the state of charge (SOC) of the battery and the power demand of vehicle, the power distribution of hybrid system is carried out. Under the experiment of hardware platform, it is verified that the strategy improves the system efficiency to more than 50\%. Jin [23] proposed a fuzzy logic EMS distributes power based on the operation mode of the vehicle and the real-time voltage of the super capacitor. Through simulation, the fuzzy logic EMS can reduce the degradation of lithium battery by $17 \%$. The EMS based on fuzzy logic rules proposed by Hemi [24] reduces the hydrogen consumption of hybrid system and prolongs the battery life.

The optimization-based energy management strategies include global optimization and real-time optimization strategies. Fletcher [25] proposed an EMS based on stochastic dynamic programming, which uses the life of fuel cell as the optimization target and extends the life of the fuel cell by $14 \%$ when the fuel consumption is only increased by 3.5\%. Chen [26] proposed an online EMS based on dynamic particle swarm optimization, which was verified by hardware-in-the-loop that the strategy can improve fuel economy. Xu [27] proposed an ECMS. By transforming the energy change of lithium battery into hydrogen consumption, the cost function was established to solve the optimal power distribution. Odeim [28] proposed a PI controller based on Pontryagin's principle. Compared with fuzzy logic controller, it has some improvements in hydrogen consumption and robustness.

Up to now, most of the existing work focuses on optimizing fuel cell economy or durability. However, the inconsistencies of batteries are not considered. Gallardo, Hoque and Omariba in references [29-31] show that: in practice, due to the influence of production conditions, battery connection mode, charging and discharging mode, ambient temperature, connection position, and other factors, the inconsistency of battery is intensified after the charging and discharging cycle, mainly reflected in the change of voltage, resistance and capacity. Therefore, the above EMS must be used in combination with the battery equalization strategy to avoid errors caused by battery inconsistency.

According to the energy conversion mode of equalization circuit, battery equalization strategy can be divided into passive equalization and active equalization. Among them, the passive equalization strategy $[32,33]$ generally uses the high SOC battery in parallel with the resistance or analog device to consume the extra energy. The advantages are simple circuit structure and control strategy. The disadvantage is energy waste and will increase the cost of battery thermal management. The active equalization [34-36] is to transfer excess power of the high SOC battery to the low SOC battery through the energy storage component, transformer or power converter. The advantage is that there is no energy waste, but the disadvantage is that their structure is generally complex, and the cost is high.

According to the above content, at present, few EMS take the battery inconsistency into account, which will lead to energy distribution error, battery damage and even security risks. The current battery equalization strategies rarely discuss how to perform the equilibrium process while meeting the power demand of vehicle. To solve these issues, this paper takes into account the inconsistency of series lithium battery pack and the energy distribution of hybrid power systems. According to the experimental results, six single battery models with different parameters are used to represent the batteries with different aging degrees in the modeling of lithium battery. A switch network control strategy based on the circuit structure of Manenti in Ref. [37] is designed. The switch network control strategy can automatically control whether the battery is connected to the circuit according to the power demand of vehicle and the SOC of all batteries in the battery pack. Then the equalization energy management strategy (EEMS) based on the switch network control strategy is designed. The EEMS divides the batteries into two types according to the SOC of all the batteries and counts the numbers of the two types of batteries in real time to make different decisions to achieve the purpose of fast equalization. By combining EEMS with ECMS through switching control, the inconsistency of lithium battery pack can be improved under the premise of ensuring the vehicle's normal operation, and the 
SOC of battery pack can be controlled to a specific value. The real-time simulation of a typical vehicle driving cycle verifies that the SEMS can balance the series lithium battery pack during the normal operation of the vehicle by controlling the switch state to improve the safety and durability of the system. Besides, it has good expansibility and no energy waste.

The rest of the paper is organized as follows. Section 2 includes three parts: Part 2.1 describes the modeling of the proton exchange membrane fuel cell. Part 2.2 describes the methods and results of the battery test, and the modeling of series lithium battery pack is described. Part 2.3 describes the modeling of the DC/DC converter. Section 3 includes two parts: Part 3.1 first introduces the circuit structure of the switch network, and then describes the specific rules of the EEMS. Part 3.2 describes the algorithm of the ECMS. Section 4 gives the simulation results and analysis. The conclusion is drawn in Section 5.

\section{Hybrid System Modeling}

Fuel cell/lithium battery hybrid system can make full use of their respective advantages. The main power is provided by the fuel cell, and the lithium battery pack is used as an auxiliary power source to provide partial power and recycle braking energy during the operation of the vehicle. The structure of the hybrid system is shown in Figure 1. The fuel cell is connected to the DC bus through a unidirectional DC/DC converter, and the lithium battery pack is connected to the bus through a bidirectional DC/DC converter to provide auxiliary power.

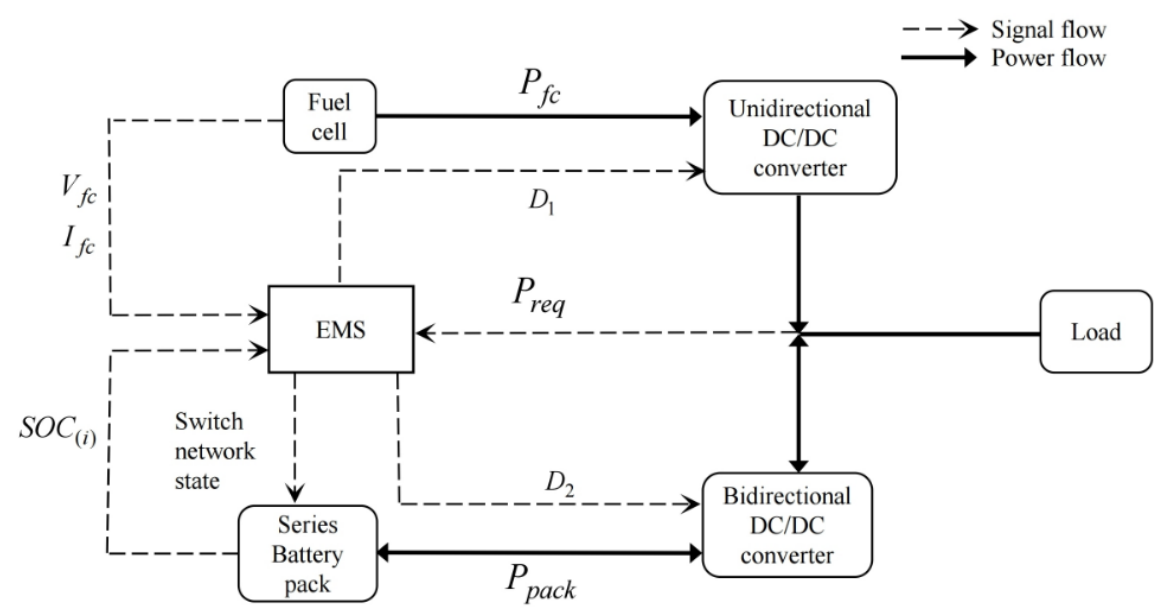

Figure 1. The structure of fuel cell/lithium battery hybrid system.

\subsection{Proton Exchange Membrane Fuel Cell Modeling}

The single cell voltage of proton exchange membrane fuel cell can be calculated by open circuit voltage, activation loss, ohmic loss and concentration loss [38]:

$$
V_{f c}=E_{o c}-V_{a c t}-V_{o h m}-V_{c o n c}
$$

The open circuit voltage is calculated according to the change of Gibbs free energy in the chemical reaction:

$$
E_{o c}=1.229-8.5 \times 10^{-4}\left(T_{f c}-298.15\right)+4.308 \times 10^{-5} T_{f c}\left[\ln \left(p_{H_{2}}\right)+0.5 \ln \left(p_{O_{2}}\right)\right]
$$

where, $T_{f c}$ is the fuel cell stack temperature. $p_{\mathrm{H}_{2}}$ and $p_{\mathrm{O}_{2}}$ are hydrogen partial pressure and oxygen partial pressure, respectively. They are expressed in atm. 
The activation loss is a result of the need to cause electron transfer and to break and form chemical bonds in the anode and cathode [39]. Part of the energy is lost in driving the chemical reaction that transfers the electrons to and from the electrodes [40]. It can be described as follows:

$$
V_{a c t}=v_{0}+v_{a}\left(1-e^{-c_{1} i}\right)
$$

where, $c_{1}$ is a constant derived from experience, and the values of $v_{0}$ and $v_{a}$ can be calculated according to the stack temperature, cathode pressure, and oxygen partial pressure:

$$
\begin{gathered}
v_{0}=0.279-8.5 \times 10^{-4}\left(T_{f c}-298.15\right)+4.308 \times 10^{-5} T_{f c}\left[\ln \left(\frac{p_{c a}-p_{s a t}}{1.01325}\right)+0.5 \ln \left(\frac{0.1173\left(p_{c a}-p_{\text {sat }}\right)}{1.01325}\right)\right] \\
v_{a}=\left(-1.618 \times 10^{-5} T_{f c}+1.618 \times 10^{-2}\right)\left(\frac{p_{\mathrm{O}_{2}}}{0.1173}+p_{\text {sat }}\right)^{2}+\left(1.8 \times 10^{-4} T_{f c}\right. \\
-0.166)\left(\frac{p_{\mathrm{O}_{2}}}{0.1173}+p_{\text {sat }}\right)+\left(-5.8 \times 10^{-4} T_{f_{c}}+0.5736\right)
\end{gathered}
$$

where, $p_{c a}, p_{c a}$, and $p_{c a}$ are expressed in bar. $i$ is the stack current density, which can be obtained by stack current $I_{f c}$ and battery activation area $A$ :

$$
i=\frac{I_{f c}}{A}
$$

the saturation pressure $p_{\text {sat }}$ is calculated as follows:

$$
\log _{10}\left(p_{\text {sat }}\right)=-1.69 \times 10^{-10} T_{f_{c}}^{4}+3.85 \times 10^{-7} T_{f_{c}}{ }^{3}-3.39 \times 10^{-4} T_{f_{c}}{ }^{2}+0.143 T_{f_{c}}-20.92
$$

the ohmic loss is caused by the resistance of the electrode material and the polymer membrane, which can be expressed as follows:

$$
\begin{gathered}
V_{o h m}=i \cdot r_{o h m} \\
r_{o h m}=\frac{t_{m}}{\sigma_{m}}
\end{gathered}
$$

where, $r_{\text {ohm }}$ is the internal electrical resistance which has the unit of $\Omega \cdot \mathrm{cm}^{2} . t_{m}$ is the thickness of the membrane and $\sigma_{m}$ is the membrane conductivity, which is a function of the membrane water content $\lambda_{m}$ and the stack temperature:

$$
\sigma_{m}=\left(b_{11} \lambda_{m}-b_{12}\right) \exp \left(b_{2}\left(\frac{1}{303}-\frac{1}{T_{f c}}\right)\right)
$$

where, $b_{11}, b_{12}$ and $b_{2}$ are constants, which are generally obtained by experience.

The concentration loss is caused by the change in the reactant concentration on the electrode surface and can be described as follows:

$$
V_{\text {conc }}=i\left(c_{2} \frac{i}{i_{\max }}\right)^{c_{3}}
$$

where, $i_{\text {max }}, c_{2}$ and $c_{3}$ are constants that depend on the temperature and the reactant partial pressure and can be determined empirically.

The fuel cell stack consists of many single cells in series, so the total voltage output is as follows:

$$
V_{s t}=n V_{f c}
$$

Table 1 is the parameter used in the fuel cell simulation. 
Table 1. The parameter used in fuel cell simulation.

\begin{tabular}{ccc}
\hline Parameter & Value & Description \\
\hline$n$ & 40 & Number of cells \\
$A$ & 280 & Activation area $\left(\mathrm{cm}^{2}\right)$ \\
$T_{f c}$ & 353 & Fuel cell temperature $(\mathrm{K})$ \\
$t_{m}$ & 0.01275 & Membrane thickness $(\mathrm{cm})$ \\
\hline
\end{tabular}

Figure 2 shows the curve of the voltage and power of the fuel cell changing with the current density.

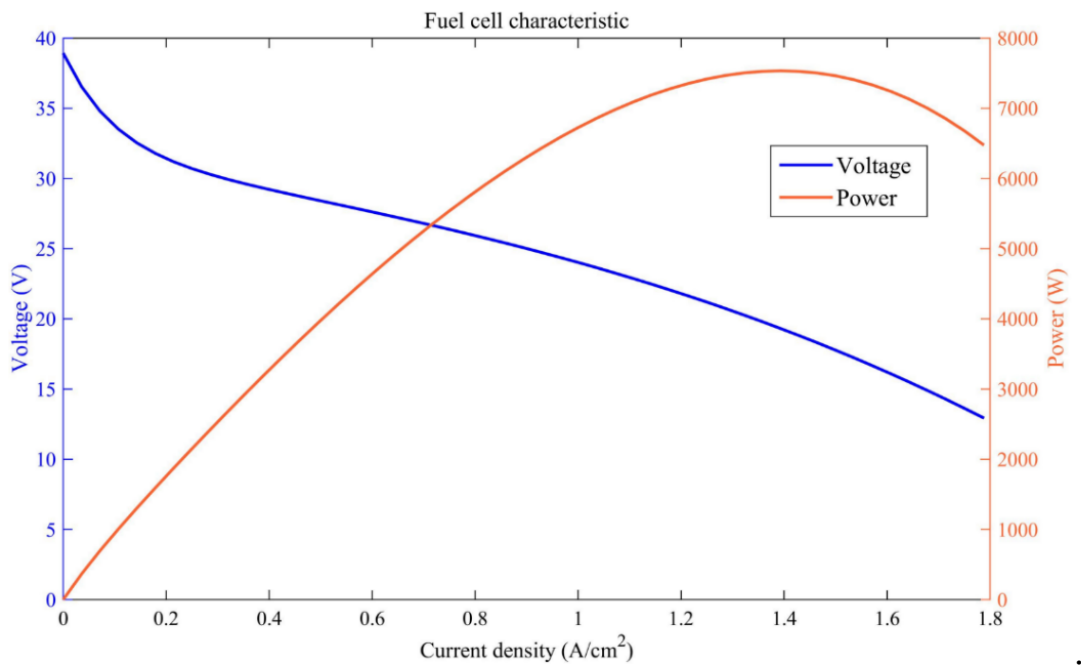

Figure 2. The voltage and power of fuel cell stack.

\subsection{Lithium Battery Pack Modeling}

Six lithium batteries with different aging degrees were tested by the Arbin battery test bench (Arbin BT-5HC-5V/100A) as shown in Figure 3. The test bench had 3 scales (100 A/10 A/1 A) and its operating voltage was $0-5 \mathrm{~V}$. The resolution of the current and voltage was $\pm 0.5 \%$. The lithium battery was placed in a temperature chamber at the temperature of $298.15 \mathrm{~K}$. The computer is used to load experiment procedures and collect data. Through the open circuit voltage test and hybrid pulse power characteristic (HPPC) test, the capacity test and parameter identification, the data of lithium battery can be obtained from Guo and Xiang's experiment in Ref. [41-44].

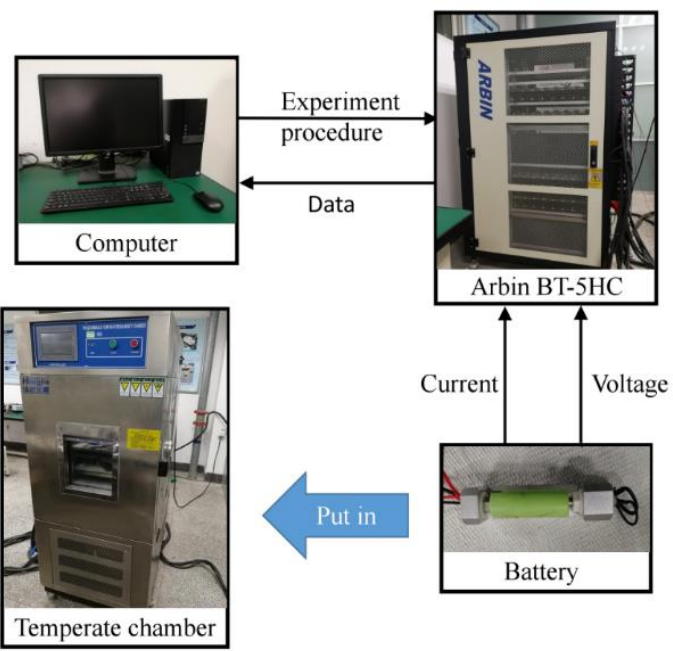

Figure 3. The test bench for battery. 
The discharge rate of the lithium battery capacity test is $1 \mathrm{C}$, and the capacity of test batteries is shown in Table 2.

Table 2. The number and capacity of test batteries.

\begin{tabular}{lcccccc}
\hline Battery number & 1 & 2 & 3 & 4 & 5 & 6 \\
\hline Capacity $(A \cdot h)$ & 2 & 1.8 & 1.6 & 1.5 & 1.2 & 1 \\
\hline
\end{tabular}

The open circuit voltage test is based on No.1 battery. Figure 4 shows the comparison between the measured data and fitted curve.

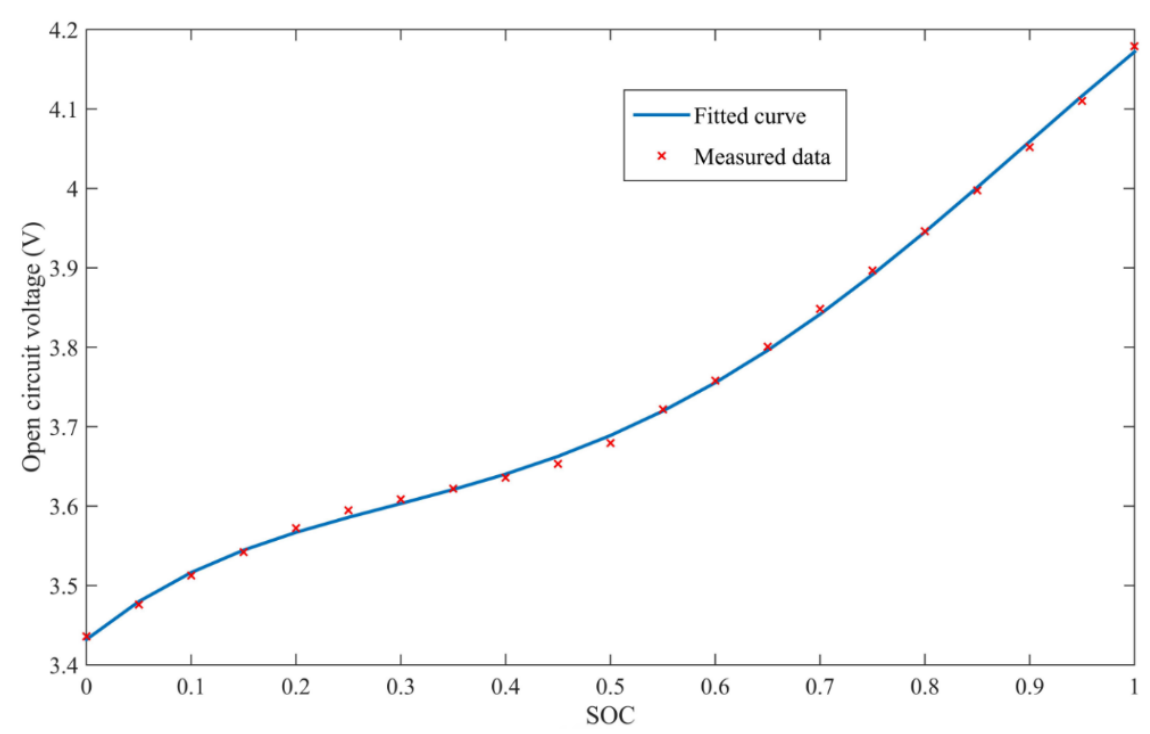

Figure 4. Comparison between the measured data and fitted curve.

Here, the fitted curve formula is: equation/formula

$$
V_{o c}=-1.834 \times S O C^{4}+4.354 \times S O C^{3}-2.869 \times S O C^{2}+1.089 \times S O C+3.432
$$

the root means square error of the fitted curve and the measured data is 0.006 , indicating that the fitted curve has high accuracy.

HPPC test is intended to determine dynamic power capacity, resistance over the battery's useable voltage range using a test profile that incorporates both discharge and regen pulses. The test profile can be seen in Ref. [45] of Jeffrey. The charge and discharge resistance of the lithium battery was measured by HPPC test. The resistance of No.1 battery is shown in Figure 5: 


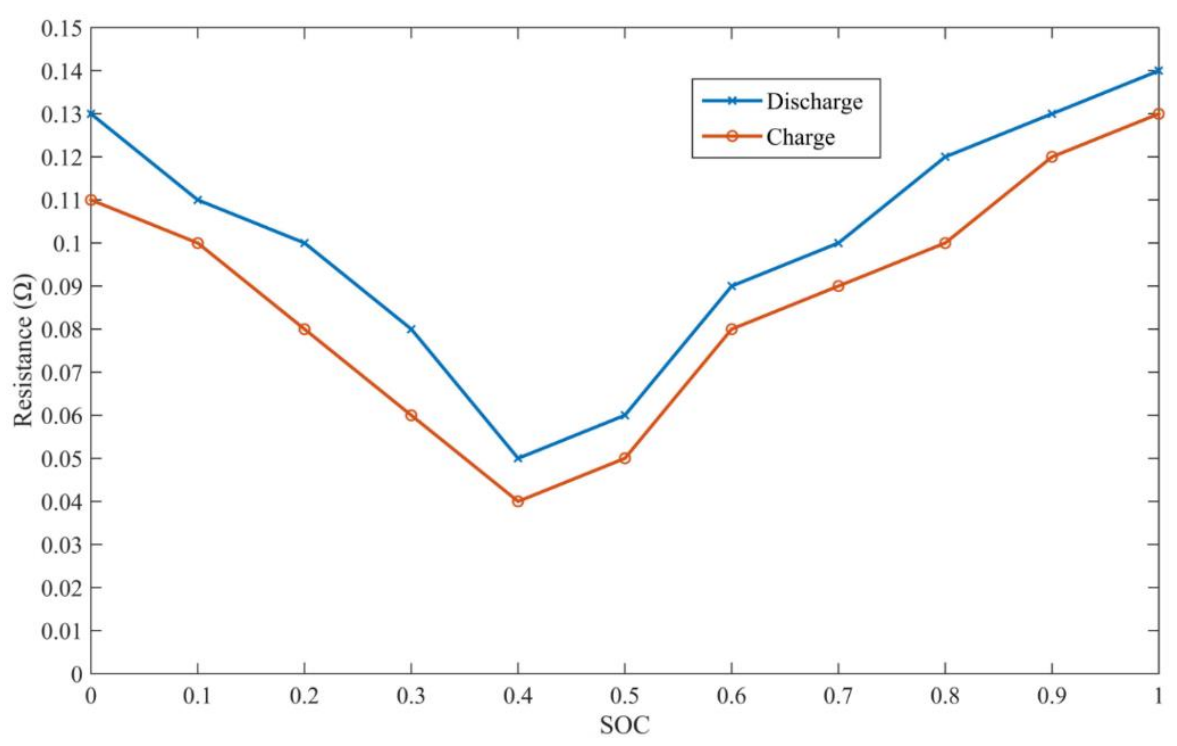

Figure 5. The resistance of No.1 battery.

According the switch network state in the Section 3, the battery in the circuit may be in two states: connected or disconnected. Therefore, the voltage and resistance of each battery also have two states (ignoring the resistance of the wire):

$$
\begin{gathered}
V_{o c}=\left\{\begin{array}{l}
V_{o c}, \text { connected } \\
0, \text { disconnected }
\end{array}\right. \\
R_{b a t}=\left\{\begin{array}{l}
R_{b a t}, \text { connected } \\
0, \text { disconnected }
\end{array}\right.
\end{gathered}
$$

The equivalent model of the lithium battery pack is the RINT model. According to Ohm's law, the output voltage $V_{\text {pack }}$ of the series lithium battery pack is as follows:

$$
V_{\text {pack }}=V_{\text {oc_pack }}-I_{\text {bat }} R_{\text {pack }}
$$

where, $I_{b a t}$ is the current of the batteries. $V_{\text {oc_pack }}$ is the sum of the open circuit voltage of all connected batteries. $R_{\text {pack }}$ is the sum of the resistance of all connected batteries. The relationship between the current and the power can be derived from Equation (16):

$$
I_{\text {bat }}=\frac{V_{\text {oc_pack }}-\sqrt{V_{\text {oc_pack }}{ }^{2}-4 R_{\text {pack }} P_{\text {pack }}}}{4 R_{\text {pack }}}
$$

where, $P_{\text {pack }}$ is the charge or discharge power of the series lithium battery pack.

For a single lithium battery, SOC can be calculated by current integration method:

$$
S O C_{t}=S O C_{t_{0}}-\frac{\int_{t_{0}}^{t} I_{b a t} d t}{Q}
$$

where, $S O C_{t_{0}}$ is the initial value of SOC and $Q$ is the capacity of the battery. Table 3 shows the parameter of single lithium battery used in the simulation: 
Table 3. Parameters of single battery.

\begin{tabular}{ccc}
\hline Parameters & Value & Description \\
\hline$I_{\max }$ & 4 & Maximum current $(A)$ \\
$V_{\max }$ & 4.15 & Charging cut-off voltage $(V)$ \\
$V_{\min }$ & 3.45 & Discharging cut-off voltage $(V)$ \\
\hline
\end{tabular}

\subsection{DC/DC Converter Modeling}

The voltages of the fuel cell and the lithium battery pack are matched to the bus voltage by unidirectional DC/DC converter and bidirectional DC/DC converter. When the system is in steady state, the function of DC/DC converter can be described by the following equations:

$$
\begin{gathered}
V_{\text {out }}=V_{\text {in }} /(1-D) \\
I_{\text {out }}=(1-D) I_{\text {in }} \cdot \eta_{d c}
\end{gathered}
$$

where, $V_{\text {in }}$ and $I_{\text {in }}$ are the input voltage and current of the converter respectively; $V_{\text {out }}$ and $I_{\text {out }}$ are the output voltage and current of the converter respectively; $\eta_{d c}$ is the efficiency of the converter; the output voltage can be controlled by the duty cycle $D$.

\section{Switched Energy Management Strategy}

The block diagram of the SEMS is shown in Figure 6. The SEMS includes two energy management strategies. The SEMS performs real-time switching between EEMS and ECMS by comparing the standard deviation of the lithium battery SOC with a threshold.

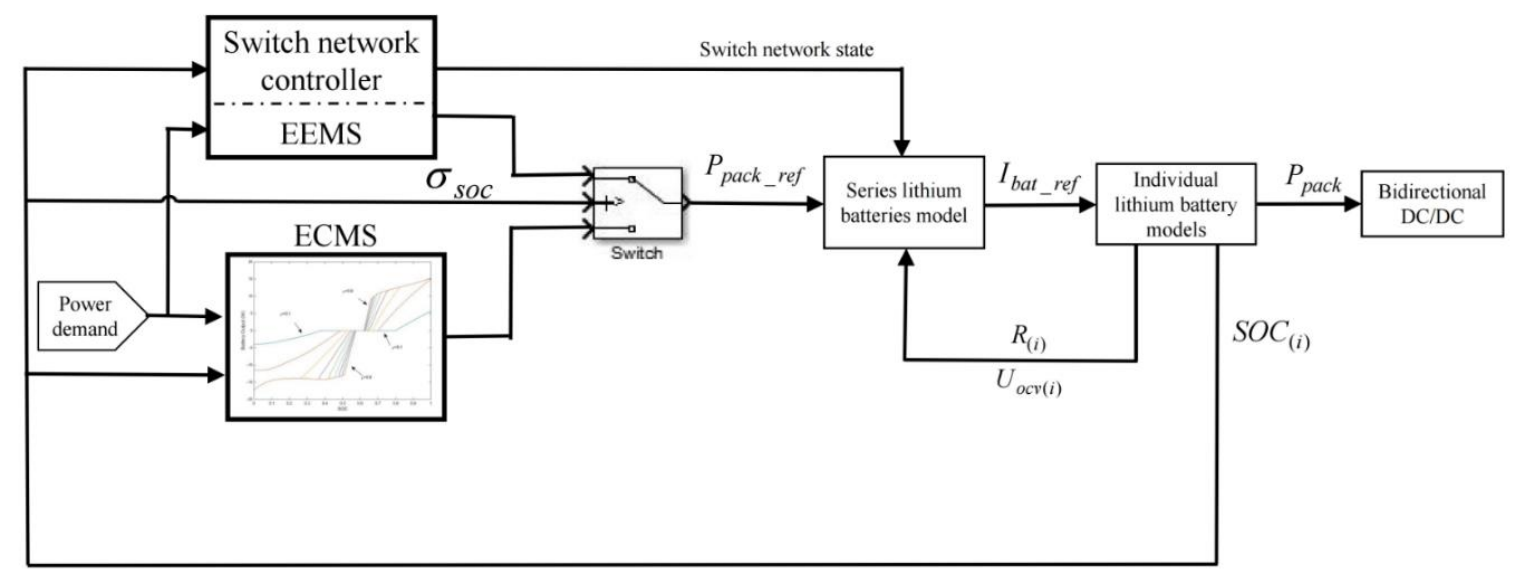

Figure 6. The block diagram of the switched energy management strategy.

When the standard deviation is greater than the threshold, it indicates that the lithium batteries are not consistent. The SEMS works in EEMS mode. In EEMS mode, the switch network controller can control whether the lithium battery is connected to the circuit by controlling the state of the switch network. When the standard deviation is less than the threshold, it indicates that the lithium batteries are consistent. The SEMS works in ECMS mode. In ECMS mode, all lithium batteries are connected to the circuit.

The flow of the SEMS is: According to the power demand and the SOC status of the current lithium battery pack, the SEMS switches to EEMS mode or ECMS mode to obtain the reference output power of the lithium battery pack $P_{\text {pack_ref }}$ and the switch network state. The series lithium battery model calculates the reference output current of the single lithium battery $I_{\text {bat_ref }}$ according to Formula (16) by reference output power $P_{\text {pack_ref }}$, switch network state, resistance and open circuit voltage of each single lithium battery. Each single lithium battery model updates the SOC status and output 
power according to the reference output current $I_{b a t \_r e f}$ and the constraint Formula (22). The fuel cell system power is calculated based on the actual output power of the lithium battery pack $P_{\text {pack }}$ and the power demand according to Equation (20) and the constraint Equation (21).

\subsection{Equalization Energy Management Strategy Based on Switch Network}

The switch network [37] shown in Figure 7 can control the number of working batteries by controlling the switches of branch and bypass. For example, when the switch $S_{11}$ is closed and $S_{12}$ is opened at the same time, the battery $B_{1}$ can be connected to the circuit. On the contrary, the battery $B_{1}$ can be disconnected. According to the SOC state of each lithium battery and the current power demand, the EEMS performs power distribution, and the switch controller performs real-time control on the switch network.

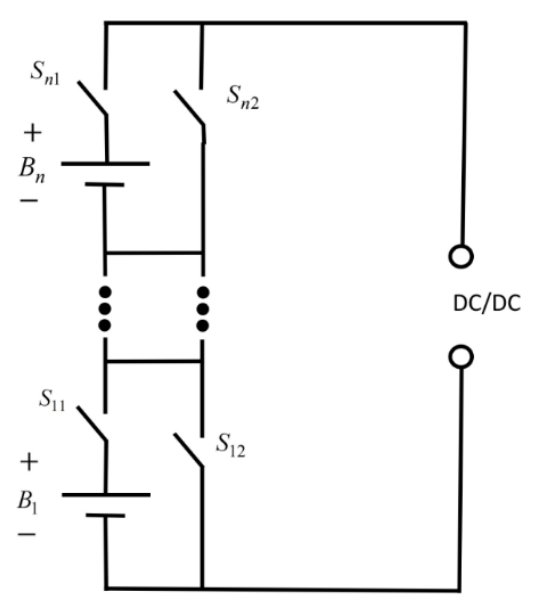

Figure 7. The structure of switch network.

The main goal of EEMS is to improve the inconsistency of series lithium batteries as soon as possible while meeting the power demand. Therefore, lithium battery can be divided into two categories: high SOC and low SOC according to whether the SOC of lithium battery is higher than the average SOC of the series lithium battery. Count the number of two types of batteries in real time and make decisions according to the number of two types of batteries and the power demand. When the number of high SOC batteries $\left(N_{\text {high }}\right)$ is greater than or equal to the number of low SOC batteries $\left(N_{\text {low }}\right)$, the power distribution and switching rules are determined as shown in Table 4.

Table 4. Rules of equalization energy management strategy (EEMS) $\left(N_{\text {high }} \geq N_{\text {low }}\right)$.

\begin{tabular}{|c|c|c|c|}
\hline State & Power Demand & $P_{\text {pack_ref }}$ & $\begin{array}{l}\text { Switch Network State } \\
\text { (Disconnect) }\end{array}$ \\
\hline 1 & $P_{l}<P_{f c m i n}$ & $P_{l}-P_{f c m i n}$ & $S O C=\max$ \\
\hline 2 & $P_{f c \min } \leq P_{l}<P_{f c \max }$ & $P_{l}-P_{f c \max }$ & $S O C \geq$ mean \\
\hline 3 & $P_{\text {fcmax }} \leq P_{l}<P_{\text {fcmax }}+N_{h \_ \text {mean }} \cdot P_{b_{-} \text {target }}$ & $\sum P_{b a t m a x}$ & $S O C<$ mean \\
\hline 4 & $\begin{array}{c}P_{f c \text { max }}+N_{h \_ \text {mean }} \cdot P_{b_{-} \text {target }} \leq P_{l}< \\
P_{f \text { cmax }}+N_{h \_ \text {min }} \cdot P_{b_{-} \text {target }}\end{array}$ & $\sum P_{\text {batmax }}$ & $S O C=\min$ \\
\hline 5 & $P_{f c \max }+N_{h_{-} \text {min }} \cdot P_{b_{-} \text {target }} \leq P_{l}$ & $\sum P_{\text {batmax }}$ & / \\
\hline
\end{tabular}

In Table $4, P_{l}$ is the current load power demand. The fuel cell maximum power $P_{f c m a x}$ and minimum power $P_{f c m i n}$ are $300 \mathrm{~W}$ and $0 \mathrm{~W}$ respectively, which is a 25 times reduction in fuel cell simulation results. $P_{b_{-} \text {target }}$ is the No.1 battery maximum reference power when the SOC of No.1 battery is equal to the SOC at equilibrium point in ECMS mode. Briefly speaking, in this paper, $P_{b_{-} \text {target }}$ is the power when the SOC of No.1 battery is 0.6 and the discharge current is $4 \mathrm{~A}$. $P_{\text {batmax }}$ is the charging or discharging power of each battery when the charging or discharging current is $I_{\max } . N$ is the number 
of batteries in the subscript state, $h$ and $l$ are higher than and lower than respectively, max, min and mean are the maximum, minimum and average value of SOC respectively. For example, $N_{h_{-} \text {mean }}$ is the number of batteries whose SOC is higher than the mean.

For state 1: Power demand is lower than the minimum power of fuel cell, which indicates that the vehicle is in the state of braking energy recovery. Therefore, the switch network control strategy is: disconnect the batteries whose SOC are equal to $\max$, and charge other batteries.

For state 2: Power demand is higher than the minimum power and lower than the maximum power of the fuel cell. Since the high SOC batteries are the majority, in order to achieve the goal of rapid equalization, the fuel cell needs to charge the low SOC batteries while meeting the power demand. The switch network control strategy is: disconnect the batteries whose SOC are higher than mean, and charge other batteries.

For state 3: Power demand is higher than the maximum power of the fuel cell and lower than the sum of the maximum power of the fuel cell and the reference power of high SOC batteries. In order to meet the power demand, the high SOC batteries outputs the maximum power, and the rest power is supplemented by the fuel cell. The switch network control strategy is: disconnect the batteries whose SOC are lower than mean.

For state 4: The batteries whose SOC are higher than min output the maximum power, and the rest power is supplemented by the fuel cell. The switch network control strategy is: disconnect the batteries whose SOC are equal to $\mathrm{min}$.

For state 5: The power demand exceeds the limit output power of the hybrid system, so all batteries are connected to the circuit for maximum power output.

When the number of high SOC batteries $\left(N_{\text {high }}\right)$ is less than the number of low SOC batteries $\left(N_{\text {low }}\right)$, only states 2 and states 3 control strategies are different. The power distribution and switching rules are determined as shown in Table 5.

Table 5. Rules of EEMS $\left(N_{\text {high }}<N_{\text {low }}\right)$.

\begin{tabular}{cccc}
\hline State & Power Demand & $P_{\text {pack_ref }}$ & $\begin{array}{c}\text { Switch Network State } \\
\text { (Disconnect) }\end{array}$ \\
\hline 6 & $P_{f c m i n} \leq P_{l}<N_{h_{\_} \text {mean }} \cdot P_{b_{-} \text {target }}$ & $P_{l}-P_{f c m i n}$ & SOC $\geq$ mean \\
7 & $N_{h_{\text {_mean }} \cdot} \cdot P_{b_{-} \text {target }} \leq P_{l}<$ & $\sum P_{\text {batmax }}$ & SOC $<$ mean \\
\hline
\end{tabular}

For state 6: Power demand is higher than the minimum power and lower than the reference power of high SOC batteries. Since the low SOC batteries are the majority, in order to achieve the goal of rapid equalization, the high SOC batteries need to supply the power. The switch network control strategy is: disconnect the batteries whose SOC are lower than mean.

For state 7: In order to meet the power demand, the high SOC batteries outputs the maximum power, and the rest power is supplemented by the fuel cell. The switch network control strategy is: disconnect the batteries whose SOC are lower than mean.

In EEMS mode, after obtaining the battery pack reference power $P_{\text {pack_ref }}$ by the above rules, the fuel cell reference power is calculated by the following equation:

$$
P_{f c_{-} r e f}=P_{l}-P_{\text {pack_ref }}
$$

and in any mode, the fuel cell and lithium battery meet the following constraints:

The actual power of the fuel cell meets the following constraint:

$$
P_{f c m i n} \leq P_{f c} \leq P_{f c m a x}
$$


The current of batteries meets the following constraint:

$$
0 \leq I_{b a t} \leq I_{\max }
$$

since the battery life and safety are closely related to the depth of discharge (DOD), the SOC of batteries meets the following constraint:

$$
S O C_{l} \leq S O C \leq S O C_{h}
$$

where, $S O C_{l}$ and $S O C_{h}$ are the lower and upper limit of SOC, respectively. If the SOC of a battery is lower than $S O C_{l}$, it can only be connected to the circuit when it is charged. If the SOC of a battery is higher than $S O C_{h}$, it can only be connected to the circuit when it is discharged.

\subsection{Equivalent Consumption Minimization Strategy}

When the standard deviation is less than the threshold, it represents the end of the equalization process. The consistency of lithium battery pack is good, which can be regarded as the SOC of each battery is equal. However, EEMS can only make SOC tend to be consistent while the demand power is satisfied and cannot control the SOC value at the end of equilibrium. Therefore, it is necessary to combine other EMS to make SOC tend to target value, and through this kind of combination, fuel economy and system durability can be considered.

ECMS belongs to the real-time optimization strategy. By transforming the power of the battery into the equivalent hydrogen consumption of the fuel cell, the power distribution among the power sources is solved to obtain the best fuel economy. It has been proved to have good fuel economy in $\mathrm{Xu}$, Garcia and Motapon's references [27,46,47].

The fuel economy optimization problem of the fuel cell/battery hybrid system can be described as an optimization problem of controlling the power of the fuel cell and the battery to minimize the total hydrogen consumption of the hybrid system under the constraints of the system, as shown in Equation (25):

$$
\begin{cases}P_{f c_{-} \text {opt }} & =\operatorname{argmin} C=\operatorname{argmin}\left(C_{f c}+k C_{\text {pack }}\right) \\ & \text { s.t. } s_{l} \leq S O C \leq s_{h} \\ & V_{\text {pack_min }} \leq V_{\text {pack }} \leq V_{\text {pack_max }} \\ & P_{f c m i n} \leq P_{f c} \leq P_{f c m a x}\end{cases}
$$

where, $s_{l}$ and $s_{h}$ are the lower and upper value of the battery pack SOC control range. $V_{\text {pack_min }}$ and $V_{\text {pack_max }}$ are the lower and upper limit of battery pack voltage, respectively. $k$ is linear coefficient, which can be expressed by:

$$
k=1-2 \mu \frac{S O C-0.5\left(s_{h}+s_{l}\right)}{s_{h}-s_{l}}
$$

where, $\mu$ is SOC balance coefficient. It determines the speed of SOC reaching the equilibrium point. The value ranges from 0 to 1 .

$C_{f c}$ is the instantaneous hydrogen consumption of the fuel cell, which can usually be expressed as a linear function of the fuel cell output power, as shown in Equation (27):

$$
C_{f c}=a P_{f c}+b
$$

$C_{\text {pack }}$ is the equivalent instantaneous hydrogen consumption of the battery pack, which can be expressed as Equation (28):

$$
C_{\text {bat }}=\left\{\begin{array}{l}
\frac{P_{\text {pack }} C_{f \_\_a v g}}{\eta_{\text {dis }} \eta_{c h g \_a v g} P_{f \_\_a v g}}, P_{\text {pack }} \geq 0 \\
P_{\text {pack }} \eta_{\text {chg }} \eta_{\text {dis_avg }} \frac{C_{f c \_a v g}}{P_{f \_\_\_v g}}, P_{\text {pack }}<0
\end{array}\right.
$$


where, $P_{\text {pack }}$ is the power of the battery pack. When discharging, $P_{\text {pack }}$ is positive; when charging, $P_{\text {pack }}$ is negative. $\eta_{\text {chg_avg }}$ and $\eta_{\text {dis_avg }}$ are the mean efficiency of charging and discharging, respectively. $P_{f_{\mathcal{C} \_a v g}}$ and $C_{f c_{\_} \_ \text {avg }}$ are the mean power and the mean hydrogen consumption. $\eta_{c h g}$ and $\eta_{d i s}$ are the charging and discharging efficiency of the battery pack, which is a function of the current SOC of the battery pack, and can be expressed as Equation (29):

$$
\left\{\begin{array}{l}
\eta_{\text {dis }}=\frac{1+\sqrt{1-\frac{4 R_{\text {dis }} P_{\text {pack }}}{V_{\text {pack }}^{2}}}}{2}, P_{\text {pack }} \geq 0 \\
\eta_{\text {chg }}=\frac{2}{1+\sqrt{1-\frac{4 R_{\text {chg }} P_{\text {pack }}}{V_{\text {pack }}}}}, P_{\text {pack }}<0
\end{array}\right.
$$

where, $R_{\text {dis }}$ and $R_{\text {chg }}$ are the battery pack discharging and charging resistance, respectively. It can be obtained by the experiment in Section 2. To simplify the presentation, the symbols are defined as follows:

$$
\left\{\begin{array}{c}
X_{\text {min }}=\sqrt{1+\frac{4 V_{\text {pack_min }}\left(V_{\text {pack_min }}-V_{\text {pack }}\right)}{V_{\text {pack }}{ }^{2}}} \\
X_{\text {max }}=\sqrt{1+\frac{4 V_{\text {pack_max }}\left(V_{\text {pack_max }}-V_{\text {pack }}\right)}{V_{\text {pack }}{ }^{2}}} \\
K=\frac{k}{\eta_{\text {ch__avg }}}
\end{array}\right.
$$

substituting Equations (26), (28)-(30) into Equation (24), the optimized power of the lithium battery pack can be obtained as follows:

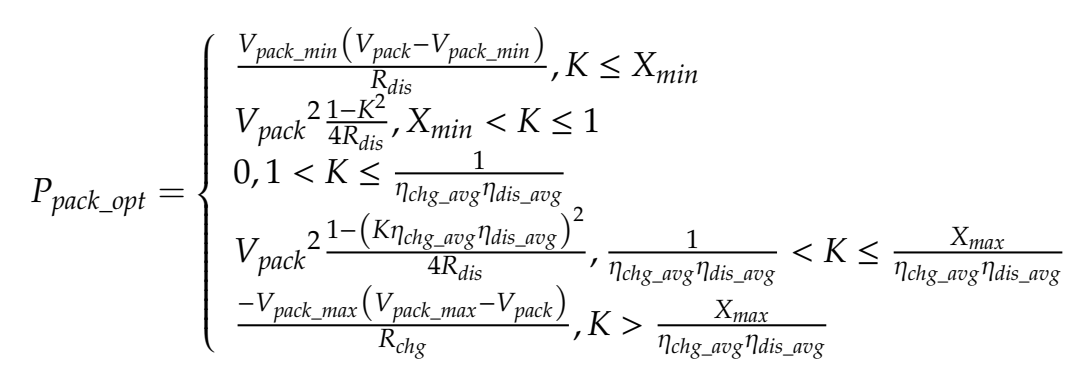

it can be seen from Equation (31) that the optimized power of the battery pack is a function of the current battery pack SOC and the balance coefficient $\mu$. Figure 8 shows the relationship between the optimized power of the battery pack and the current SOC when the balance coefficient $\mu$ changes from 0 to 1.

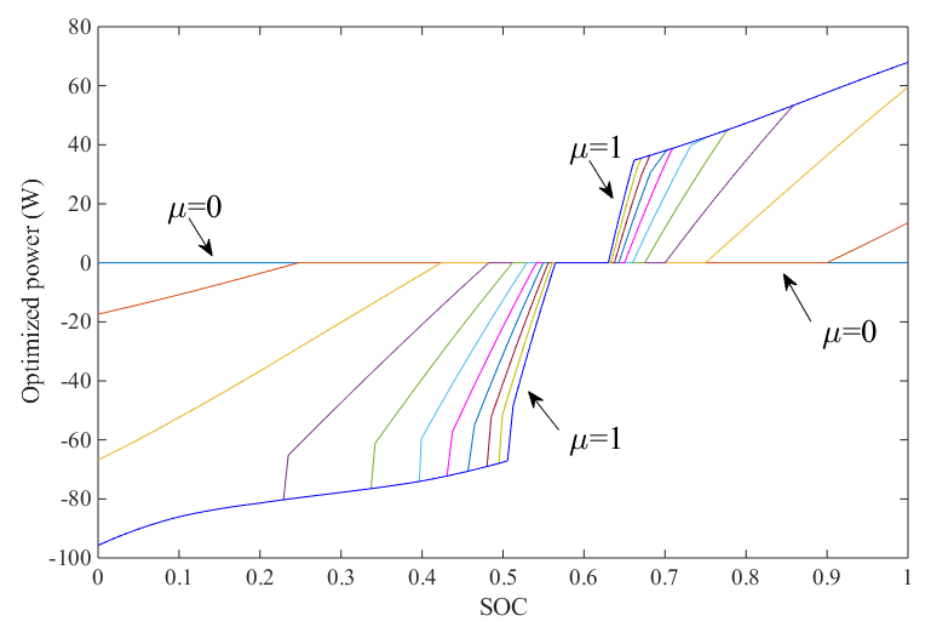

Figure 8. Relationship between the optimized power and state of charge (SOC). 


\section{Verification and Discussion}

To verify that the SEMS can not only meet the power demand for vehicle to work, but also ameliorate the inconsistency of series lithium battery pack, a real-time simulation under a new city European driving cycle (NEDC) condition is conducted. In order to match the power of the 6 series batteries, it was also reduced 25 times in the simulation. Figure 9 shows the power demand in the simulation.

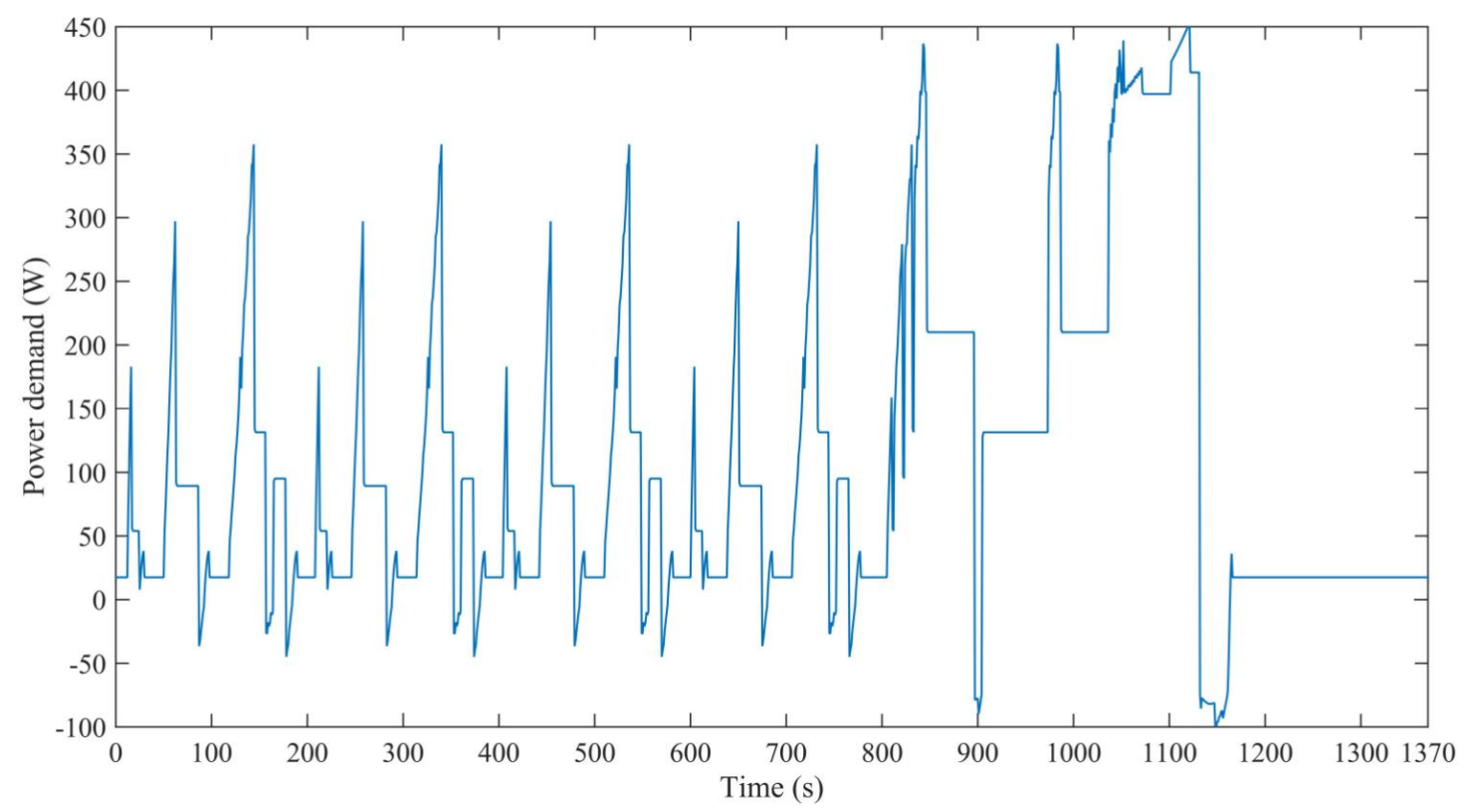

Figure 9. The power demand in simulation.

It can be seen that the entire process lasts about $1370 \mathrm{~s}$, and the peak power is $450 \mathrm{~W}$. When the power value is positive, it denotes that at this moment, the hybrid power system provides the energy to the vehicles. When the power value is below zero, it denotes that the vehicle is recycling the energy during braking. In this simulation, two different initial SOC distribution conditions of battery pack are set as: $N_{\text {high }} \geq N_{\text {low }}$ and $N_{\text {high }}<N_{\text {low }}$. The threshold of the switch is set as 0.001 . The sampling time is set as $1 \mathrm{~s}$. The $S O C_{l}$ and $S O C_{h}$ in Equation (24) are set as 0.1 and 0.9, respectively. $\mu$ is set as 0.6 in Equation (26). $s_{l}$ and $s_{h}$ are set as 0.4 and 0.8 , respectively. Therefore, in ECMs mode, SOC will eventually tend to be around 0.6.

Under the first case $\left(N_{\text {high }} \geq N_{\text {low }}\right)$, the initial values of SOC from the No.1 battery to the No.6 battery are respectively set as: $0.35,0.45,0.6,0.62,0.65,0.68$. Figure 10 shows the results of the power demand and the output power of each energy source. 


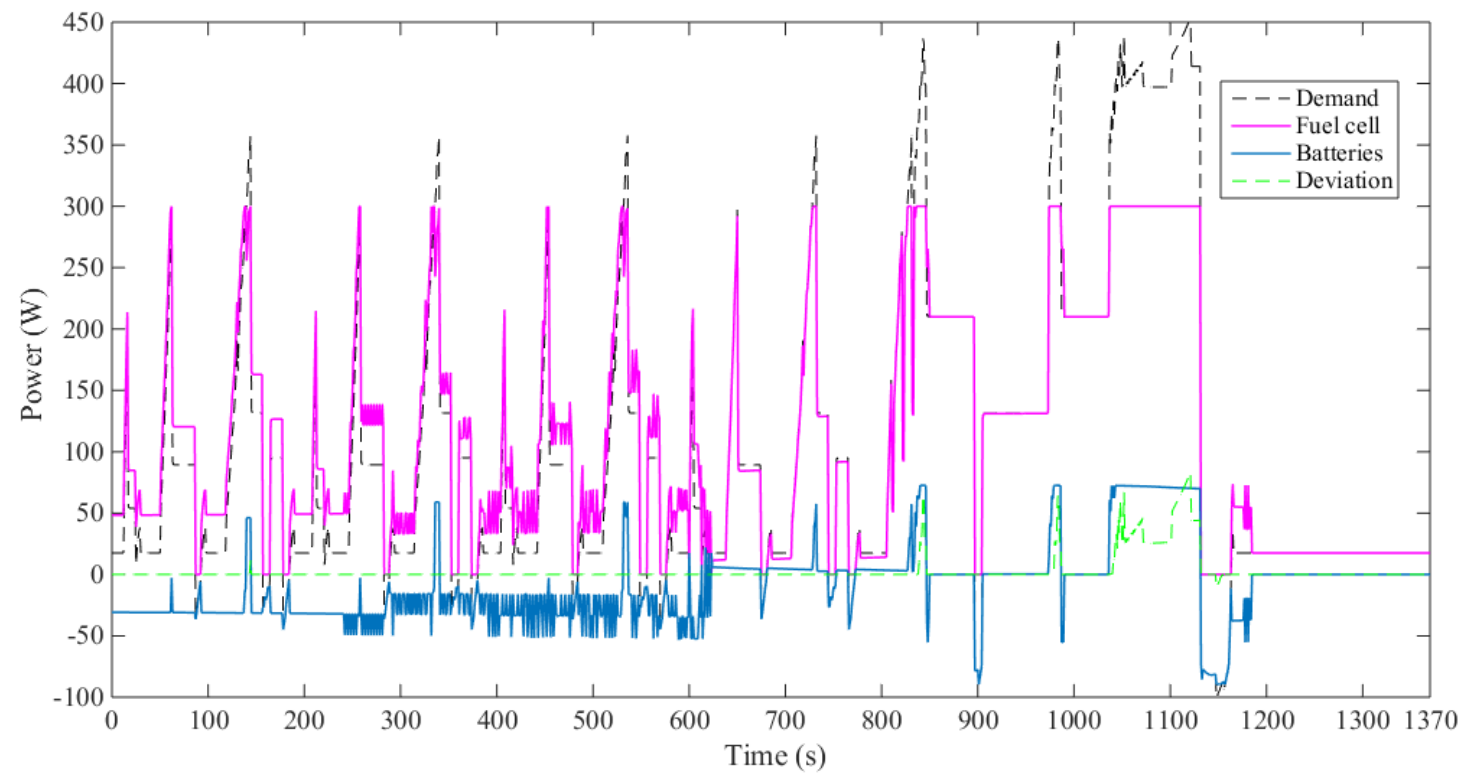

Figure 10. The power demand and the output power of each energy source.

In Figure 10, the green dotted line represents the deviation between the power demand and the power that the hybrid system provides. It can be seen during $800 \mathrm{~s}$ to $1200 \mathrm{~s}$, there are some periods when power demand exceeds the limit output power of hybrid power system. Thus, both the fuel cell and the batteries output the maximum power. During other periods, the EMS meets the power demands.

Figure 11 is the SOC changes of each battery and the standard deviation $\sigma_{S O C}$ of the battery pack. Figures 12 and 13 are the current of working batteries and the state change of the SEMS. In the first 600 $\mathrm{s}, \sigma_{S O C}$ is higher than the threshold, the series lithium battery pack shows poor consistency. Besides, there are only the No.1 battery and the No.2 battery keeping at the low SOC state. On most occasions, the power demand is lower than the maximum power of the fuel cell, so the control strategy usually works at state 2 where fuel cells supply power to the vehicle and the batteries. At state 2, the switch network control strategy can make the batteries whose SOC is higher than mean disconnected, and with time on, the No.1 battery and the No.2 battery are charged. At $240 \mathrm{~s}$, after SOC of the No. 3 battery arrives at the mean, then it fluctuates around the mean with control cycle. And at $280 \mathrm{~s}$, the SOC of the No. 2 battery reaches the average value. As the procedure goes on, the SOC of each battery gets close to the mean. At last, when it is $620 \mathrm{~s}, \sigma_{S O C}$ is lower than the threshold, which denotes the SOC of the lithium battery pack is similar and the equilibrium process finished. Then the SEMS turns into the ECMS mode (state 8), where all the batteries are connected into the circuit. Due to the different aging conditions of each battery in the lithium battery pack, their capacity and internal resistance are in different states. Thus, in ECMS mode, even though each battery is charged or discharged with the same current, their SOC changes and output power are still different. In the first case, it can be seen in Figure 11, the SOC of all batteries is 0.66 when the equilibrium process finished. It is very close to the equilibrium point 0.6 , the reference output power and the current of the battery pack under ECMS mode are small. Therefore, the SOC of each battery changes slowly, and the state of SEMS does not change very frequently in Figure 13. At $1040 \mathrm{~s}$, the power demand exceeds the limit output power of the hybrid system, and both the fuel cell and the lithium battery are discharged with the maximum power. Since the capacity of the No.6 battery is the smallest, its SOC varies the fastest. Finally, when $\sigma_{S O C}$ is higher than the threshold, which denotes that the inconsistency of the battery pack is higher than its limit value, then the SEMS turns into the EEMS mode. After $1180 \mathrm{~s}$, the second equilibrium process end, the SEMS turns into ECMS mode. 


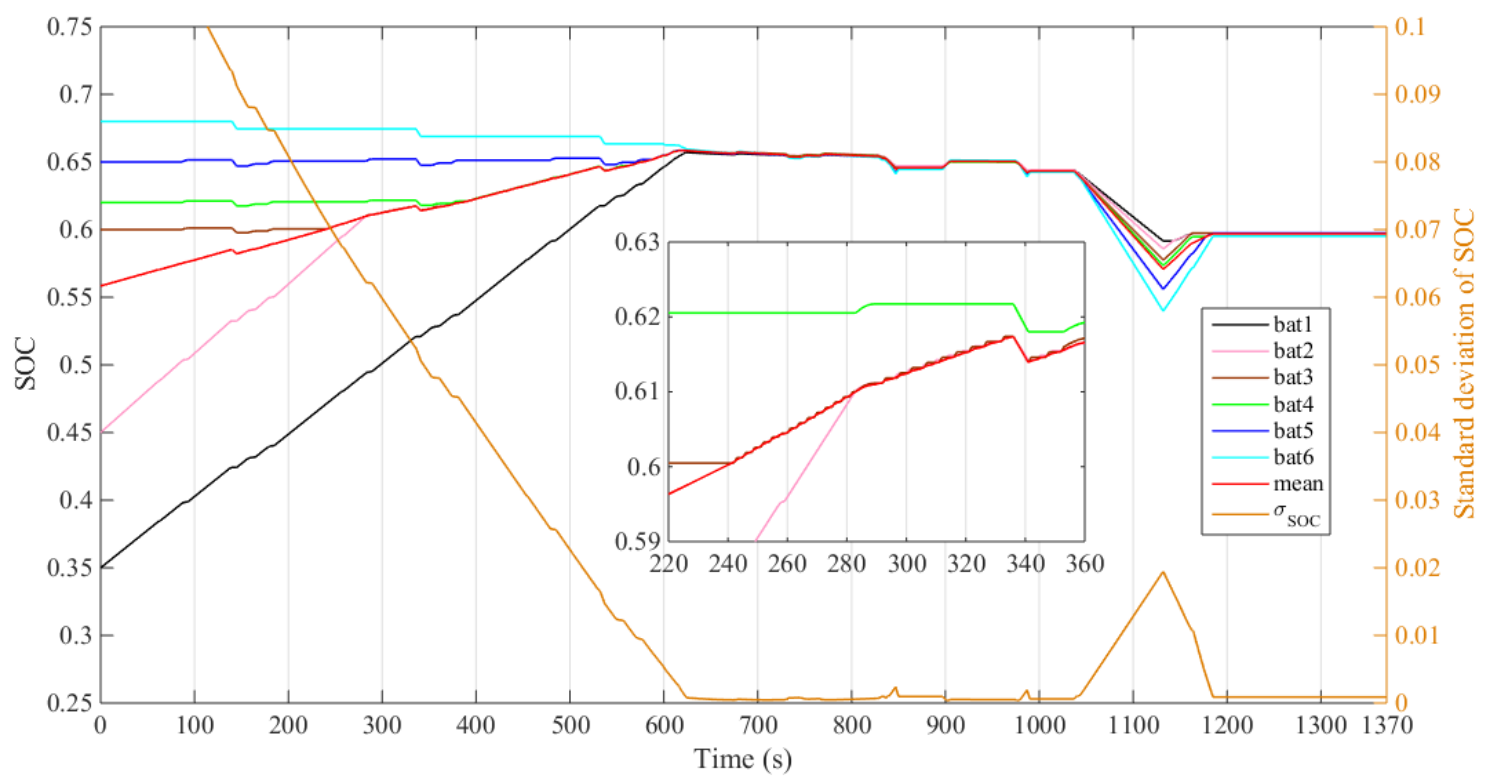

Figure 11. The SOC change of each battery.

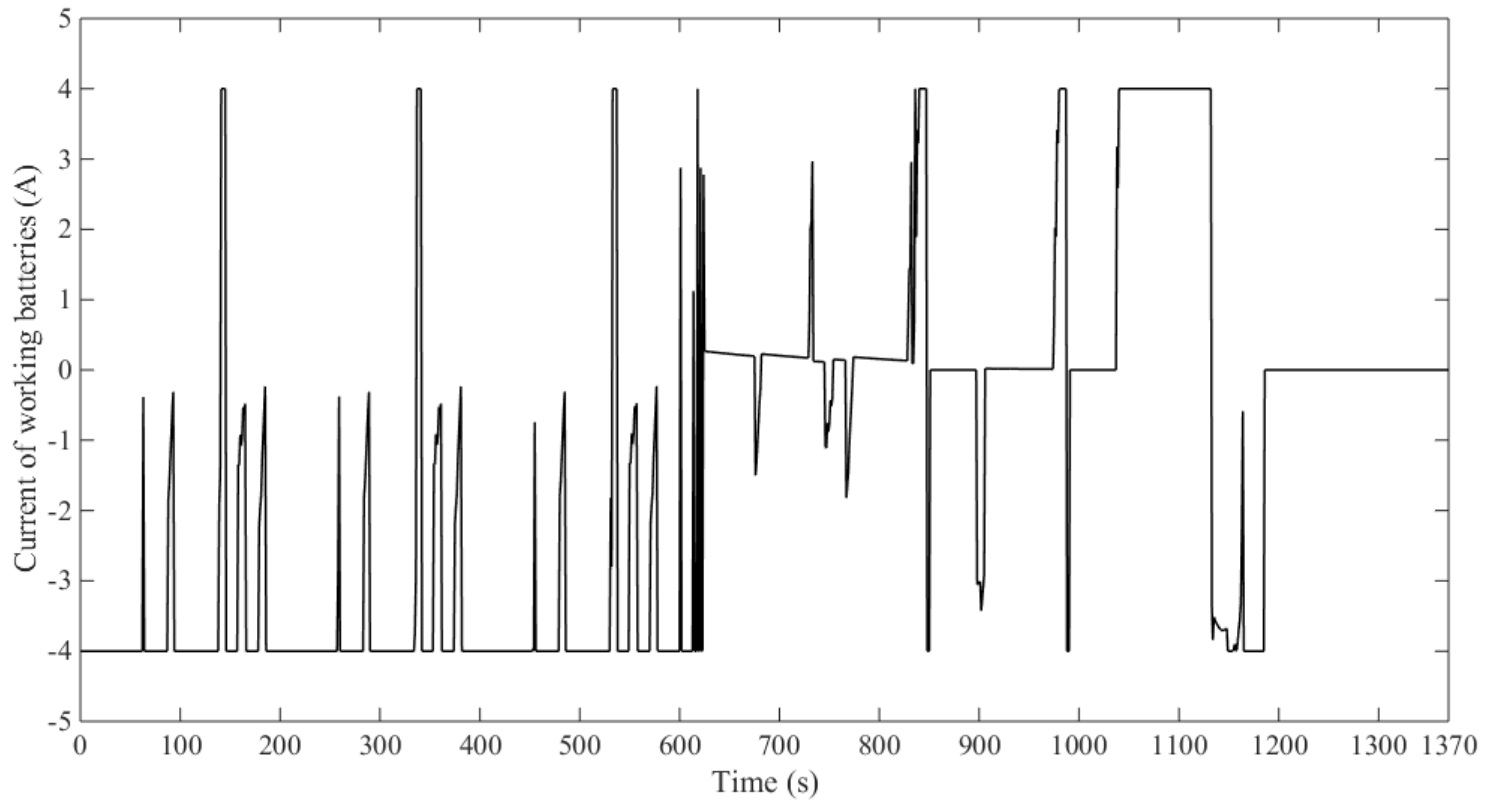

Figure 12. The current of working batteries. 


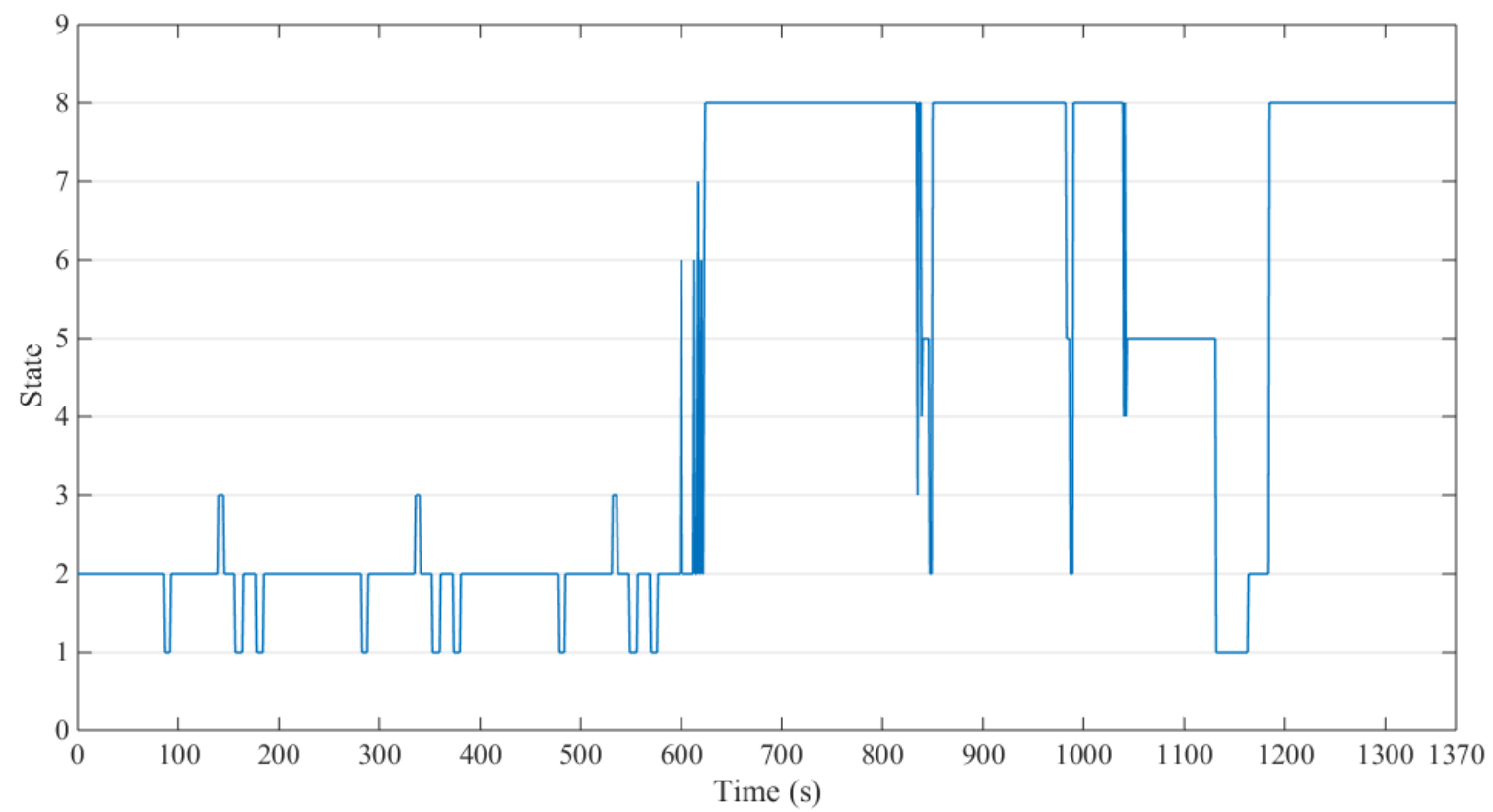

Figure 13. The state change of the switched energy management strategy.

For the second case, the simulation is also carried out, while the initial value of SOC is set as: 0.45 , $0.35,0.15,0.1,0.08,0.05$. Figure 14 shows the results of the power demand and the output power of each energy source.

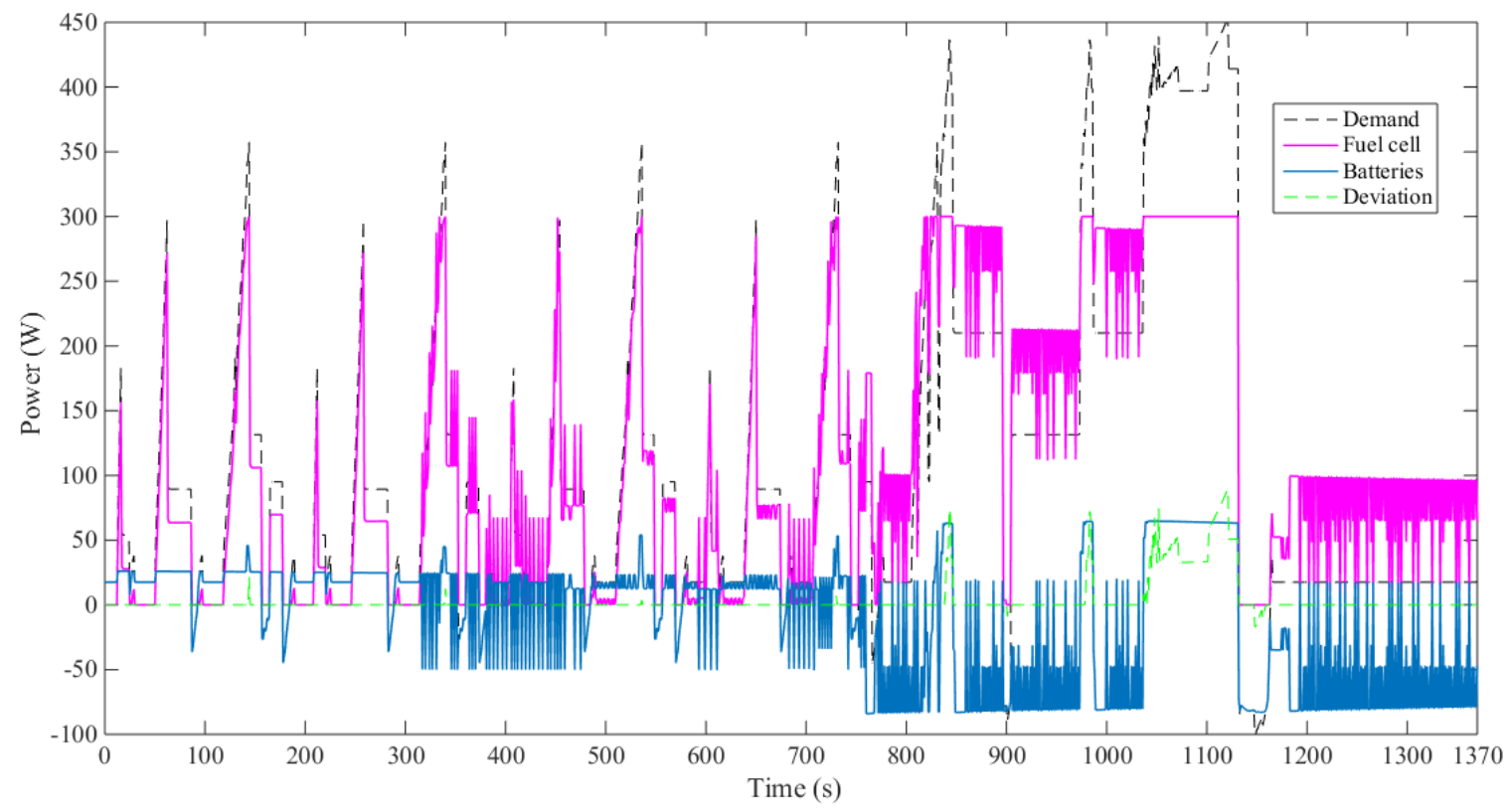

Figure 14. The power demand and the output power of each energy source.

It can be seen by comparing the power distribution results with that under the first case, the lithium battery pack is more likely at discharging state. From the deviation curve, although the distribution method is different, the SEMS can satisfy the power demand when the maximum output power of the hybrid power system is above the power demand.

Figures 15-17 are also the SOC change of each battery and the standard deviation $\sigma_{S O C}$ of the battery pack, the current of working batteries and the state change of the SEMS under the second case. During the first $780 \mathrm{~s}, \sigma_{S O C}$ is higher than the threshold, the inconsistency of the series lithium 
battery pack is severe, and No.1 battery and No.2 battery are at high SOC state. The SEMS mostly works at state 6 and state 7 . Meanwhile, the switch network control strategy disconnect the batteries whose SOC is lower than the mean. When the power demand is not high, the power is supplied by the batteries in the high SOC state. When the power demand is high, the high SOC batteries outputs the maximum power, and the fuel cell supply power when necessary. With the No.1 battery and No.2 battery discharging, mean continues to decline. When it is $320 \mathrm{~s}$, the SOC of the No.3 battery reaches the mean. And then it fluctuates around the mean with control cycle. As the procedure goes on, all batteries SOC are tend to be consistent at $760 \mathrm{~s}$, the equilibrium process finished. The SEMS turns into the ECMS mode. However, unlike the first case, the SOC of all batteries is 0.14 when the equilibrium process finished in the second case. It is far away from the equilibrium point 0.6 . Therefore, it can be seen in Figures 8 and 16, the SEMS charge all batteries with high current in ECMS mode. It causes the SOC of batteries to change rapidly until $\sigma_{S O C}$ is higher than the threshold, and the SEMS turns into the EEMS mode again. Therefore, the SEMS switches back and forth between EEMS and ECMS mode during $760 \mathrm{~s}$ to $1040 \mathrm{~s}$. The power demand exceeds the limit output power of the hybrid system during $1040 \mathrm{~s}$ to $1180 \mathrm{~s}$, and all batteries are discharged with the maximum power. After $1180 \mathrm{~s}$, The SEMS returned to charging batteries in ECMS mode and equalizing in EEMS mode at most of the time. And the SOC of batteries will be controlled around 0.6 at last. The enlarged image in the upper right corner in Figure 15 shows the over-discharge protection function in Equation (24) of the SEMS. In Figure 17, the SEMS is in state 4 during $142 \mathrm{~s}$ to $144 \mathrm{~s}$. According to the state 4 of in EEMS mode, the SOC of No.5 battery is higher than the min (the SOC of No.6 battery), so it should be discharged with the maximum current. However, its SOC during this period is 0.082, which is lower than the $S O C_{l}$ in Equation (24). In order to prevent the DOD from exceeding the limit, the No. 5 battery is disconnected from the circuit and is only connected to the circuit during charging. It can also be seen that the SOC of No.4 battery is higher than the $S O C_{l}$, so the No.4 battery is discharged, resulting in the SOC of No.4 battery falling to 0.1 .

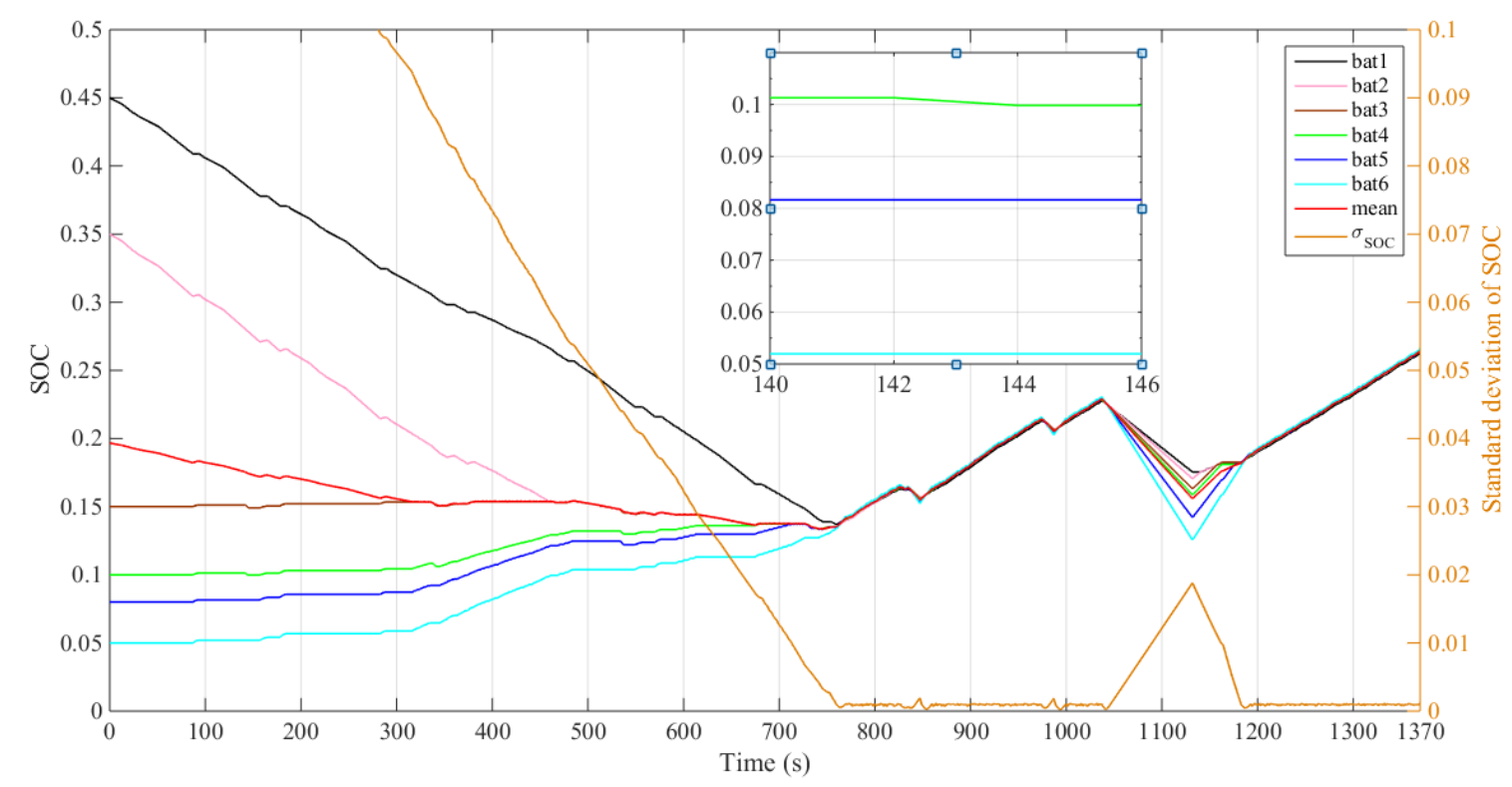

Figure 15. The SOC change of each battery. 


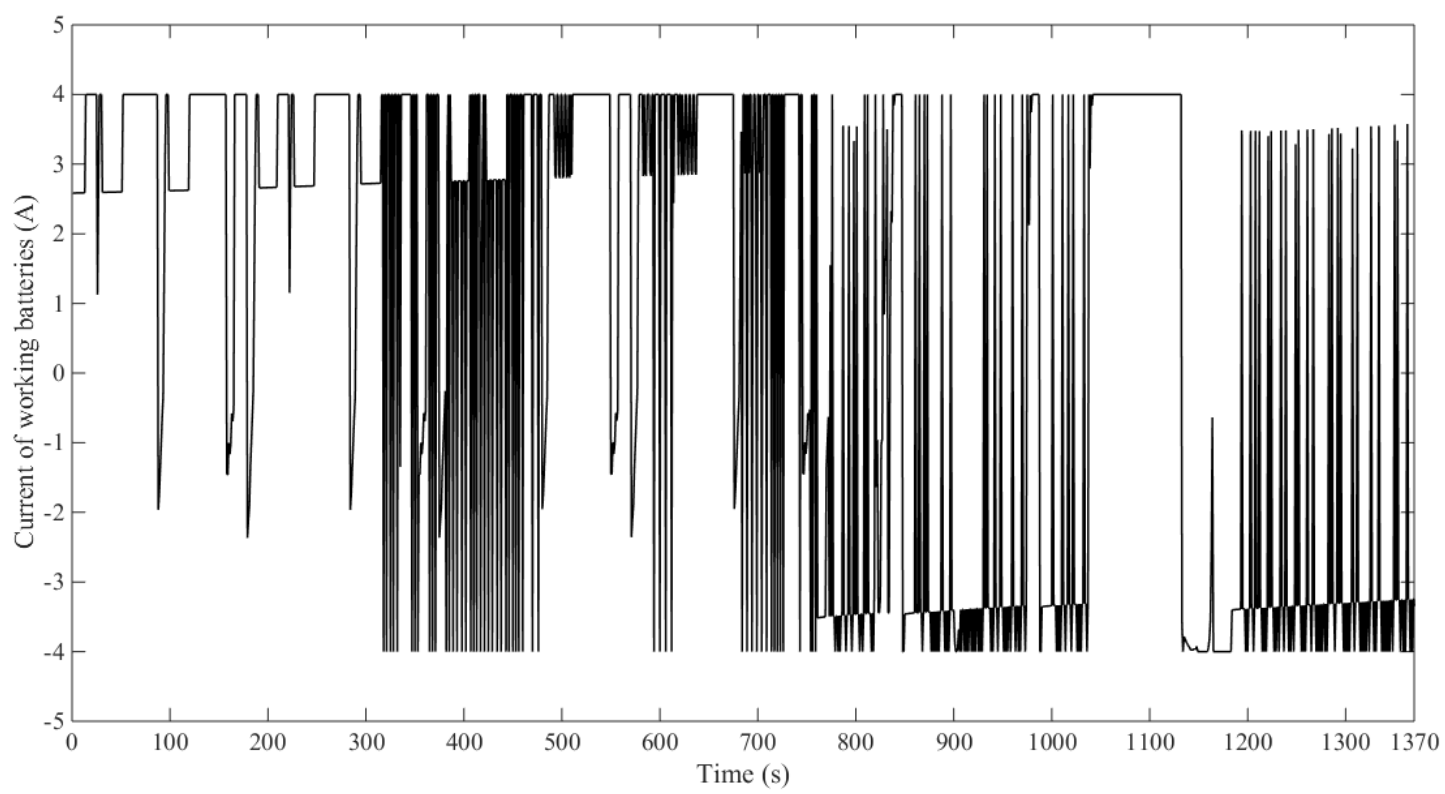

Figure 16. The current of working batteries.

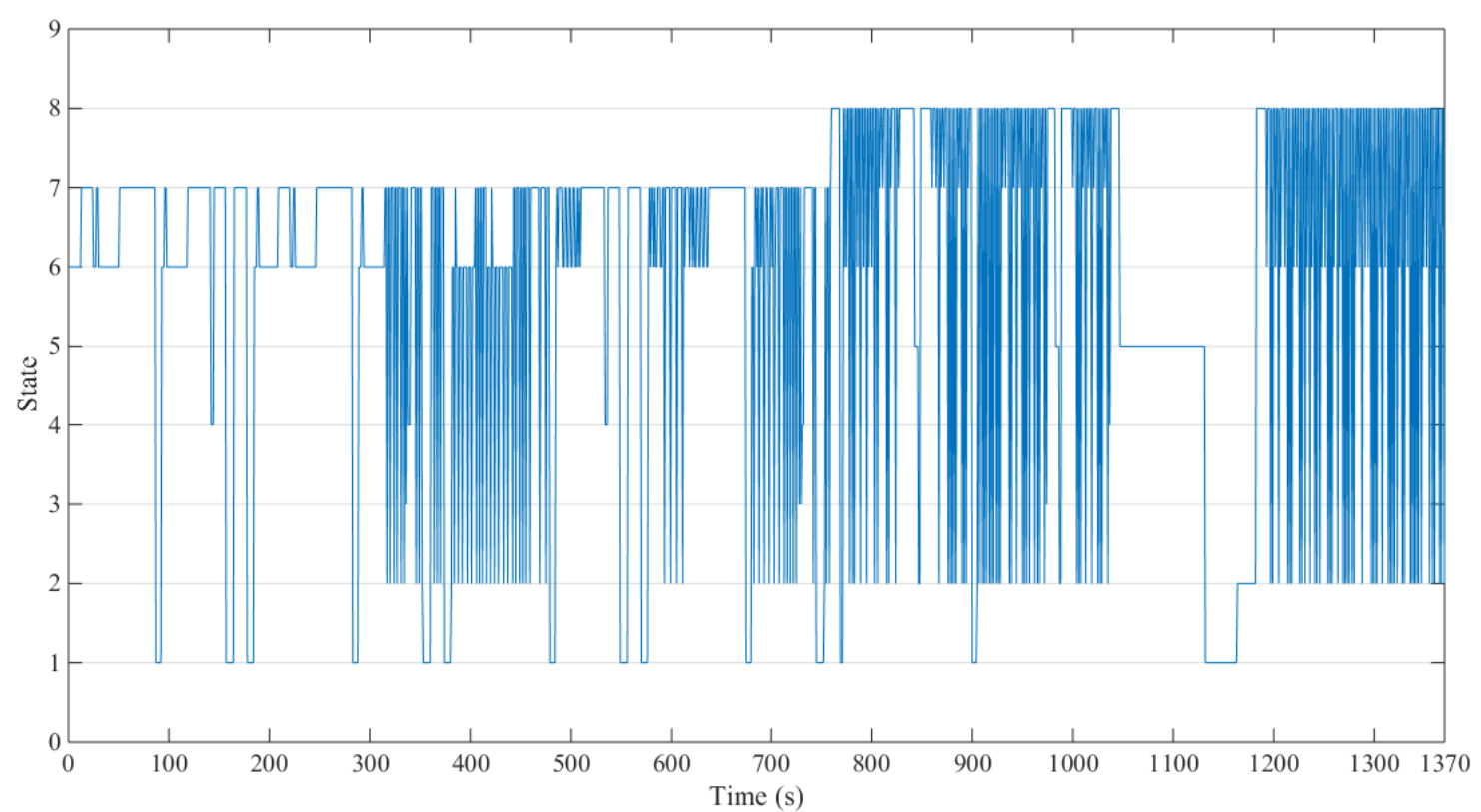

Figure 17. The state change of the switched energy management strategy.

In order to verify the effect of the threshold on the equalization quality, some data are listed in Table 6. $\sigma_{\max }$ is the maximum value of the $\sigma_{S O C}$ from the time when the battery pack reaches equilibrium for the first time to the end of the driving cycle (except the time when the demand power exceeds the limit of hybrid system). The switching times is the sum of the switching times of all battery switches in the entire driving cycle. The equalization time is the time when the battery pack reaches equilibrium for the first time. 
Table 6. Simulation results to verify the effect of current sampling time.

\begin{tabular}{ccccc}
\hline Initial & Threshold & $\sigma_{\text {max }}$ & Switching Times & Equalization Time (s) \\
\hline Case1 & $1 \times 10^{-3}$ & $1.01 \times 10^{-3}$ & 700 & 624 \\
Case1 & $0.5 \times 10^{-3}$ & $0.64 \times 10^{-3}$ & 835 & 627 \\
Case 2 & $1 \times 10^{-3}$ & $1.16 \times 10^{-3}$ & 862 & 760 \\
Case2 & $0.5 \times 10^{-3}$ & $0.67 \times 10^{-3}$ & 892 & 762 \\
\hline
\end{tabular}

It can be seen from Table 6 that as the threshold decreases, the battery inconsistency becomes better. This means less safety risk for the battery pack. Alas, reducing the threshold means that more switching times are needed, and the life of the switch network will be shortened. As the threshold decreases, the equalization time increases, but the increase is not obvious. In actual system design, priority should be given to battery inconsistency and the life of the switch network.

\section{Conclusions}

Inconsistency of battery will lead to security hazard and capacity degradation. And the key issue of EMS is to the energy distribution in hybrid systems. However, few EMS take the battery inconsistency into account, which will lead to energy distribution error, battery damage and even security risks. The current battery equalization strategy rarely discusses how to perform the equilibrium process while meeting the power demand of vehicle. To solve these problems, a method is proposed in this paper.

Firstly, a hybrid power system of fuel cell and lithium battery is established based on the simulation of fuel cell and the test results of lithium batteries. Six single battery models with different parameters are used to represent the batteries with different aging degrees in the modeling of lithium battery. Then, a switch control strategy based on the circuit structure of Manenti in Ref. [37] is designed to control the connected state of batteries. After that, an EEMS based on the switch control strategy is designed to improve the inconsistency of the battery pack. ECMS is used to control the range of SOC and ensure the efficiency of the system. The whole EMS (SEMS) switching between EEMS and ECMS in real time based on the comparison of $\sigma_{S O C}$ with a threshold. In the Matlab/Simulink environment, NEDC working condition was selected for simulation verification. The results show that the SEMS can ameliorate the inconsistency of series lithium battery pack by distribute the power of fuel cell and the series battery pack under the premise of ensuring the vehicle's normal operation. In case 1 and case 2, the inconsistency of lithium battery pack is reduced to below the threshold value for the first time, which costs about $700 \mathrm{~s}$ on average. After that time, when the power demand does not exceed the limit of the hybrid system, the inconsistency of the battery pack is effectively controlled. In the whole driving cycle, the number of switching times is about 800 and the selection of threshold affects its equalization quality and switch network life. Therefore, it can be seen that the SEMS can improve the safety and durability of the system, save equalization time. Besides, it has good expansibility and no energy waste. However, there is a disadvantage: with the increase of the number of batteries in series, the number of switches will increase rapidly due to the characteristics of the switch network.

There are some limitations in this article: there is no model for quantitative description of battery life improvement. The battery degradation model and the effect of working conditions on the battery life will be considered for further verification. The future work will optimize the fuel economy of EEMS according to the resistance distribution of lithium battery. In addition, the response speed and durability of fuel cell will be considered in the power distribution method.

Author Contributions: X.C., G.H. and F.G. proposed the idea based on the research status, and accomplished the first draft; X.C., F.G. and M.Y. conceived and designed the experiments; J.H. and M.Y. conducted the experiments and analyzed data; X.C., F.G. and G.H. revised the paper. All authors have read and agreed to the published version of the manuscript.

Funding: This research was funded by Sichuan Science and Technology Program, grant number: 2019ZDZX0028, 2018GZ0388 and 2019YFH0096.

Conflicts of Interest: The authors declare no conflict of interest. 


\section{Nomenclature}

\begin{tabular}{|c|c|}
\hline \multicolumn{2}{|l|}{ Symbols } \\
\hline$V$ & Voltage, $V$ \\
\hline$E_{o c}$ & open circuit voltage of fuel cell, $V$ \\
\hline$T$ & temperature, $K$ \\
\hline$p$ & pressure, atm or bar \\
\hline$i$ & current density, $A \mathrm{~cm}^{-2}$ \\
\hline$I$ & current, $A$ \\
\hline$A$ & activation area of fuel cell, $\mathrm{cm}^{2}$ \\
\hline$r_{o h m}$ & internal electrical resistance of fuel cell, $\Omega \mathrm{cm}^{2}$ \\
\hline$t_{m}$ & membrane thickness, $\mathrm{cm}$ \\
\hline$\sigma_{m}$ & membrane conductivity, $(\Omega \mathrm{cm})^{-1}$ \\
\hline$\lambda_{m}$ & membrane water content \\
\hline$n$ & number of cells \\
\hline$R$ & resistance, $\Omega$ \\
\hline$P$ & power, $W$ \\
\hline$Q$ & battery capacity, $A h$ \\
\hline$D$ & duty cycle of DC/DC converter \\
\hline$\eta$ & efficiency \\
\hline$N$ & number of specific batteries \\
\hline max, min, mean & the maximum, minimum and average value of SOC \\
\hline$S O C_{l}, S O C_{h}$ & the lower and upper limit of SOC \\
\hline$s_{l}, s_{h}$ & the lower and upper value of SOC control range \\
\hline C & hydrogen consumption, $g s^{-1}$ \\
\hline$k$ & linear coefficient \\
\hline$\mu$ & balance coefficient \\
\hline$X_{\min }, X_{\max }$ & custom parameters \\
\hline K & custom parameter \\
\hline \multicolumn{2}{|c|}{ Subscripts, Superscripts } \\
\hline act & activation loss \\
\hline $\operatorname{avg}$ & average \\
\hline bat & single battery \\
\hline b_target & battery whose SOC at target value \\
\hline$c a$ & cathode \\
\hline $\operatorname{chg}$ & charge \\
\hline conc & concentration loss \\
\hline$d c$ & DC/DC converter \\
\hline dis & discharge \\
\hline$f_{c}$ & fuel cell \\
\hline h_mean & higher than mean value of SOC \\
\hline$h \_$min & higher than minimum value of SOC \\
\hline in & input \\
\hline$l$ & load \\
\hline $\max , \min$ & the upper and lower limit \\
\hline$o c$ & open circuit \\
\hline ohm & ohmic loss \\
\hline opt & optimal \\
\hline out & output \\
\hline pack & battery pack \\
\hline ref & reference \\
\hline st & fuel cell stack \\
\hline sat & saturation \\
\hline
\end{tabular}




\section{Nomenclature}

$\begin{array}{ll}\text { Abbreviations } & \\ \text { DOD } & \text { depth of discharge } \\ \text { EEMS } & \text { equalization energy management strategy } \\ \text { EMS } & \text { energy management strategy } \\ \text { HPPC } & \text { hybrid pulse power characteristic } \\ \text { SEMS } & \text { switched energy management strategy } \\ \text { SOC } & \text { state of charge }\end{array}$

\section{References}

1. Lin, B.; Xu, M. Regional Differences on CO2 Emission Efficiency in Metallurgical Industry of China. Energy Policy 2018, 120, 302-311. [CrossRef]

2. Andersson, F.N.; Opper, S.; Khalid, U. Are Capitalists Green? Firm Ownership and Provincial CO2 Emissions in China. Energy Policy 2018, 123, 349-359. [CrossRef]

3. Mikayilov, J.I.; Galeotti, M.; Hasanov, F.J. The Impact of Economic Growth on CO2 Emissions in Azerbaijan. J. Clean. Prod. 2018, 197, 1558-1572. [CrossRef]

4. Dulebenets, M.A. The Green Vessel Scheduling Problem with Transit Time Requirements in a Liner Shipping Route with Emission Control Areas. Alex. Eng. J. 2018, 57, 331-342. [CrossRef]

5. Lo, P.L.; Martini, G.; Porta, F.; Scotti, D. The Determinants of CO2 Emissions of Air Transport Passenger Traffic: An Analysis of Lombardy (Italy). Transp. Policy 2018. [CrossRef]

6. Dulebenets, M.A. Advantages and Disadvantages from Enforcing Emission Restrictions within Emission Control Areas. Marit. Bus. Rev. 2016, 1, 107-132. [CrossRef]

7. Adom, P.K.; Kwakwa, P.A.; Amankwaa, A. The Long-Run Effects of Economic, Demographic, and Political Indices on Actual and Potential CO2 Emissions. J. Environ. Manag. 2018, 218, 516-526. [CrossRef]

8. Chu, S.; Majumdar, A. Opportunities and Challenges for a Sustainable Energy Future. Nature 2012, 488, 294-303. [CrossRef]

9. Un-Noor, F.; Padmanaban, S.; Mihet-Popa, L.; Mollah, M.N.; Hossain, E. A Comprehensive Study of Key Electric Vehicle (EV) Components, Technologies, Challenges, Impacts, and Future Direction of Development. Energies 2017, 10, 1217. [CrossRef]

10. Andwari, A.M.; Pesiridis, A.; Rajoo, S.; Martinez-Botas, R.; Esfahanian, V. A Review of Battery Electric Vehicle Technology and Readiness Levels. Renew. Sustain. Renew. Sustain. Energy Rev. 2017, 78, 414-430. [CrossRef]

11. Pollet, B.G.; Staffell, I.; Shang, J.L. Current Status of Hybrid, Battery and Fuel Cell Electric Vehicles: From Electrochemistry to Market Prospects. Electrochim. Acta 2012, 84, 235-249. [CrossRef]

12. Li, H.; Ravey, A.; N'Diaye, A.; Djerdir, A. A Novel Equivalent Consumption Minimization Strategy for Hybrid Electric Vehicle Powered by Fuel Cell, Battery and Supercapacitor. J. Power Source 2018, 395, 262-270. [CrossRef]

13. Chen, C.X.; Shang, F.; Salameh, M.; Krishnamurthy, M. Challenges and Advancements in Fast Charging Solutions for EVs: A Technological Review. IEEE Transp. Electrif. Conf. Expo 2018, 695-701.

14. Lu, X.Q.; Qu, Y.; Wang, Y.D.; Qin, C.; Liu, G. A Comprehensive Review on Hybrid Power System for PEMFC-HEV: Issues and Strategies. Energy Convers. Manag. 2018, 171, 1273-1291. [CrossRef]

15. Gao, J.W.; Li, M.; Hu, Y.F.; Chen, H.; Ma, Y. Challenges and Developments of Automotive Fuel Cell Hybrid Power System and Control. Sci. China (Inf. Sci.) 2019, 62, 50-74. [CrossRef]

16. Zhang, P.; Yan, F.W.; Du, C.Q. A Comprehensive Analysis of Energy Management Strategies for Hybrid Electric Vehicles Based on Bibliometrics. Renew. Sustain. Energy Rev. 2015, 48, 88-104. [CrossRef]

17. Geetha, A.; Subramani, C. A Comprehensive Review on Energy Management Strategies of Hybrid Energy Storage System for Electric Vehicles. Int. J. Energy Res. 2017, 41, 1817-1834. [CrossRef]

18. Kasimalla, V.K.R.; Srinivasulu, G.N.; Velisala, V. A Review on Energy Allocation of Fuel Cell/Battery/Ultracapacitor for Hybrid Electric vehicles. Int. J. Energy Res. 2018, 42, 4263-4283. [CrossRef]

19. Sulaiman, N.; Hannan, M.A.; Mohamed, A.; Ker, P.J.; Majlan, E.H.; Wan Daud, W.R. Optimization of Energy Management System for Fuel-Cell Hybrid Electric Vehicles: Issues and Recommendations. Appl. Energy 2018, 228, 2061-2079. [CrossRef] 
20. Yue, M.L.; Jemei, S.; Gouriveau, R.; Zerhouni, N. Review on Health-Conscious Energy Management Strategies for Fuel Cell Hybrid Electric Vehicles: Degradation Models and Strategies. Int. J. Hydrogen Energy 2019, 44, 6844-6861. [CrossRef]

21. Li, Q.; Yang, H.Q.; Han, Y.; Li, M.; Chen, W.R. A State Machine Strategy Based on Droop Control for an Energy Management System of PEMFC-Battery-Supercapacitor Hybrid Tramway. Int. J. Hydrogen Energy 2016, 41, 16148-16159. [CrossRef]

22. Xiao, D.; Wang, Q.T. The Research of Energy Management Strategy for Fuel Cell Hybrid Vehicle. In Proceedings of the International Conference on Industrial Control and Electronics Engineering, Xi'an, China, 23-25 August 2012.

23. Jin, F.N.; Wang, M.Q.; Hu, C.J. A fuzzy Logic Based Power Management Strategy for Hybrid Energy Storage System in Hybrid Electric Vehicles Considering Battery Degradation. In Proceedings of the IEEE Transportation Electrification Conference and Expo (ITEC), Dearborn, MI, USA, 26-29 June 2016.

24. Hemi, H.; Ghouili, J.; Cheriti, A. A Real Time Fuzzy Logic Power Management Strategy for a Fuel Cell Vehicle. Energy Convers. Manag. 2014, 80, 63-70. [CrossRef]

25. Fletcher, T.; Thring, R.; Watkinson, M. An Energy Management Strategy to Concurrently Optimize Fuel Consumption \& PEM Fuel Cell Lifetime in a Hybrid Vehicle. Int. J. Hydrogen Energy 2016, 41, 21503-21515.

26. Chen, S.Y.; Wu, C.H.; Hung, Y.H.; Chung, C.T. Optimal Strategies of Energy Management Integrated with Transmission Control for a Hybrid Electric Vehicle Using Dynamic Particle Swarm Optimization. Energy 2018, 160, 154-170. [CrossRef]

27. Xu, L.F.; Li, J.Q.; Hua, J.F.; Li, X.J.; Ouyang, M.G. Optimal Vehicle Control Strategy of a Fuel Cell/Battery Hybrid City Bus. Int. J. Hydrogen Energy 2009, 34, 7323-7333. [CrossRef]

28. Odeim, F.; Roes, J.; Wulbeck, L.; Heinzel, A. Power Management Optimization of Fuel Cell/Battery Hybrid Vehicles with Experimental Validation. J. Power Sources 2014, 252, 333-343. [CrossRef]

29. Gallardo-Lozano, J.; Romero-Cadaval, E.; Milanes-Montero, M.I. Battery Equalization Active Methods. J. Power Sources 2014, 246, 934-949. [CrossRef]

30. Hoque, M.M.; Hanna, M.A.; Mohamed, A.; Ayob, A. Battery Charge Equalization Controller in Electric Vehicle Applications: A review. Renew. Sustain. Energy Rev. 2017, 75, 1363-1385. [CrossRef]

31. Omariba, Z.B.; Zhang, L.J.; Sun, D.B. Review of Battery Cell Balancing Methodologies for Optimizing Battery Pack Performance in Electric Vehicles. IEEE Access 2019, 7, 129335-129352. [CrossRef]

32. Eghtedarpour, N.; Farjah, E. Distributed Charge/Discharge Control of Energy Storages in a Renewable-Energy-Based DC Micro-Grid. Renew. Power Gener. 2014, 8, 45-57. [CrossRef]

33. Teofilo, V.L.; Merritt, L.V.; Hollandsworth, R.P. Advanced Lithium Ion Battery Charger. IEEE Aerosp. Electron. Syst. Mag. 2002, 12, 30-36. [CrossRef]

34. Baughman, A.C.; Ferdowsi, M. Double-Tiered Switched-Capacitor Battery Charge Equalization Technique. IEEE Trans. Ind. Electron. 2008, 55, 2277-2285. [CrossRef]

35. Park, S.H.; Park, K.B.; Kim, H.S.; Moon, G.W.; Youn, M.J. Single-Magnetic Cell-To-Cell Charge Equalization Converter with Reduced Number of Transformer Windings. IEEE Trans. Power Electron. 2012, 27, 2900-2911. [CrossRef]

36. Moo, C.S.; Hsieh, Y.C.; Tsai, I.S. Charge Equalization for Series-Connected Batteries. IEEE Trans. Aerosp. Electron. Syst. 2003, 39, 704-710. [CrossRef]

37. Manenti, A.; Abba, A.; Merati, A.; Savaresi, S.M.; Geraci, A. A New BMS Architecture Based on Cell Redundancy. IEEE Trans. Ind. Electron. 2011, 58, 4314-4322. [CrossRef]

38. Pukrushpan, J.T. Modeling and Control of Fuel Cell Systems and Fuel Processors, 3rd ed; The University of Michigan: Ann Arbor, MG, USA, 2003; pp. 26-36.

39. Lee, J.H.; Lalk, T.R.; Appleby, A.J. Modeling Electrochemical Performance in Large Scale Proton Exchange Membrane Fuel Cell Stacks. J. Power Sources 1998, 70, 258-268. [CrossRef]

40. Larminie, J.; Dicks, A. Fuel Cell Systems Explained; John Wiley \& Sons Inc.: West Sussex, UK, 2000.

41. Guo, F.; Hu, G.D.; Hong, R. A Parameter Adaptive Method with Dead Zone for State of Charge and Parameter Estimation of Lithium-Ion Batteries. J. Power Sources 2018, 402, 174-182. [CrossRef]

42. Guo, F.; Hu, G.D.; Xiang, S.; Zhou, P.K.; Hong, R.; Xiong, N. A Multi-Scale Parameter Adaptive Method for State of Charge and Parameter Estimation of Lithium-Ion Batteries Using Dual Kalman filters. Energy 2019, 178, 79-88. [CrossRef] 
43. Xiang, S.; Hu, G.D.; Huang, R.S.; Guo, F.; Zhou, P.K. Lithium-Ion Battery Online Rapid State-of-Power Estimation under Multiple Constraints. Energies 2018, 11, 283. [CrossRef]

44. Guo, F.; Hu, G.D.; Zhou, P.K.; Huang, T.X.; Chen, X.; Ye, M.Q.; He, J.J. The Equivalent Circuit Battery Model Parameter Sensitivity Analysis for Lithium-Ion Batteries by Monte Carlo Simulation. Int. J. Energy Res. 2019, 1-12. [CrossRef]

45. Idaho National Engineering \& Environmental Laboratory. Battery Test Manual for Plug-In Hybrid Electric Vehicles; Assistant Secretary for Energy Efficiency and Renewable Energy (EE) Idaho Operations Office: Idaho Falls, ID, USA, 2010; pp. 5-8.

46. Garcia, P.; Torreglosa, J.P.; Fernandez, L.M.; Jurado, F. Viability Study of a FC-battery-SC Tramway Controlled by Equivalent Consumption Minimization Strategy. Int. J. Hydrogen Energy 2012, 37, 9368-9382. [CrossRef]

47. Motapon, S.N.; Dessaint, L.A.; Al-Haddad, K. A Comparative Study of Energy Management Schemes for a Fuel-Cell Hybrid Emergency Power System of More-Electric Aircraft. IEEE Trans. Ind. Electron. 2014, 61, 1320-1334. [CrossRef]

(C) 2020 by the authors. Licensee MDPI, Basel, Switzerland. This article is an open access article distributed under the terms and conditions of the Creative Commons Attribution (CC BY) license (http://creativecommons.org/licenses/by/4.0/). 